\title{
Brette Pearl Spar Mable (BPSM): a potential recoverable catalyst as a renewable source of biodiesel from Thevetia peruviana seed oil for the benefit of sustainable development in West Africa
}

\author{
T. F. Adepoju ${ }^{1,2^{*}}$, B. E. Olatunbosun², O. M. Olatunji ${ }^{2}$ and M. A. Ibeh ${ }^{1,2}$
}

\begin{abstract}
Background: The energy requirements are globally on a rapid escalation, as technology advances, which is also true for a developing country like Nigeria, which is dependent on fossil fuels and its derivatives. Apart from its adverse effect on its economy, it has also negative impacts on the health and the environment, in general. However, investments in renewable energy are faced by the competitive oil prices, the very high investment cost for renewable energy, and high local electricity prices. This paper appraises the attractiveness of investing in renewable energy sources over the continued use of non-edible oil for electricity generation.

Methods: This paper explores the application of biomass seed oil to produce a renewable fuel (biodiesel) using heterogeneous base catalyst. Meanwhile, two-step processes were employed to produce the biofuel. In the first step (esterification), the acid value of the oil was reduced to the recommended limit (FFA $\leq 1.5$ ) using $\mathrm{H}_{2} \mathrm{SO}_{4}$, while in the second step (transesterification), the catalyst calcination of grounded Brette Pearl Spar Mable (BPSM) pre-soaked in methanol was used as a biobase for biodiesel production. For the optimization, minitab response surface (MRS) and artificial neural network (ANN) were employed to model and optimize the process variables responsible for the optimum production of the oil and the biodiesel.

Results: The result presented showed that T. peruviana seed was found to be rich in oil with an average yield of $44.00 \%$ $(W / W)$, and the oil was highly unsaturated with a high FFA. The maximum experimental biodiesel yield obtained was 86. $00 \%$ at a catalyst amount of $4 \mathrm{~g}$, a reaction time of $70 \mathrm{~min}$, and a methanol/oil ratio of $0.1(\mathrm{v} / \mathrm{V})$. This result was validated in triplicate under the same conditions, which yielded $85.70 \%(v / V)$ for MRS and $85.98 \%(v / V)$ for ANN. Furthermore, the optimization results also indicated that the $p$ values $(p<0.05)$ of the model terms were significant, and the accuracy of the models achieved by MRS and ANN based on $R^{2}$ depict that both optimization tools gave good predictions of $R^{2}$ (MRS: $R^{2}=99.98 \%$ and ANN: $R^{2}=99.97 \%$ ). The properties of the biodiesel, as described in other earlier reports using the same feedstock with different catalysts, indicated that the produced biodiesel had properties which agreed to those reported in the literature.

(Continued on next page)
\end{abstract}

\footnotetext{
* Correspondence: avogadros2002@yahoo.com; tundedepoju@aksu.edu.ng

${ }^{1}$ Chemical/Petrochemical Engineering Department, Akwa-lbom State

University, Ikot Akpaden, Mkpat Enin L.G.A., Akwa-lbom State, Nigeria

${ }^{2}$ Agricultural Engineering Department, Akwa-lbom State University, Ikot

Akpaden, Mkpat Enin L.G.A., Akwa-lbom State, Nigeria
} 
(Continued from previous page)

Conclusions: T. peruviana seed has proved to be a good biomass raw material for oil production, and its conversion to biofuel using a heterogeneous biobase catalyst showed its suitability as a renewable environmental friendly fuel. Government should invest in more sustainable sources of energy by imposing law for the use of non-edible oil or decreasing the price of electricity.

Keywords: T. peruviana oilseeds, Minitab response surface (MRS), Artificial neural network (ANN), Brette Pearl Spar Mable, Catalyst calcination, Esterification, Transesterification

\section{Background}

In recent decades, biodiesel has blossomed as a greener and new renewable alternative to petroleum diesel, which is a non-toxic, non-aligned, carbon, sulfur, and aromatics free fuel $[1,2]$. Biodiesel can be said to be an option to conventional diesel which is transformed from vegetable oils in the presence of a primary alcohol and homogeneous catalyst, typically followed by base transesterification of naturally occurring triglycerides [3]. It has been reported that biodiesel and petroleum diesel have similar physicochemical properties in terms of their performance in an engine as a fuel [4]. Furthermore, it has also been established that, biodiesel blended along with up to $20 \%$ conventional diesel, could be used as a fuel for diesel engines [5].

Prior to the transesterification, oils were usually extracted from oil seeds through various methods such as mechanical [6-8], pressurized solvent extraction [9], soxhlet extraction [10], ultrasonic extraction [11, 12], aqueous enzymatic oil extraction (AEOE) [13, 14], stirring and shaking extraction [15] to mention a few. These methods have been reported to be used for the extraction of vegetable oils and other plant essential components, each with intrinsic advantages and shortcomings [16]. Mechanical pressing is not only the oldest and easiest method widely used, but also a method which produces oil of low value. Meanwhile, in the literature [17], the use of supercritical $\mathrm{CO}_{2}$ extraction was reported, the oil yield obtained was higher compared to that obtained from using solvent extraction. Though the produced oil has high purity, it also has high operating and investment costs. Solvent extraction, however, has various advantages, including high yield, less turbidity, as well as environmentally friendly and cost-effective properties [18, 19] as in the case of an extraction of oil from Jatropha curcus, described by Kim et al. [20]. All three, Umer et al. [21], Betiku et al. [22], and Adepoju et al. [23], studied the solvent extraction of oil from Moringa oleifera and sorrel seed and Chrysophyllum albidium oilseeds, respectively. In addition, Adepoju et al. [23] also examined the quality characterization of Moringa oleifera oil. In another study, Betiku et al. [24] investigated the solvent extraction of oil from Beniseed (Sesamum indicum) oilseeds. These oils however have already been applied as feedstocks in many applications, such as paint, pharmaceuticals, cosmetics, and others.
The use of seed oil has already been demonstrated by Rudolf Diesel, but owing to its high viscosity, partial ignition, deposition of particulate matters and lower volatility, it cannot suitably work like a conventional fuel in a modern engine designed for modern fuel, [25]. Hence, different techniques such as pyrolysis [26], microemulsion [27], and transesterification [28] have been applied to overcome these problems. Among these, transesterification has been studied and reported to be most effective, time-saving and economical, when blended or used directly in either a modern engine or diesel fuel engine, respectively [29, 30].

Nevertheless, transesterification of biodiesel produced from the refined edible oil is not viable, owing to food threats and high production cost. Therefore, non-edible vegetable oil is a good alternative to overcome the problems with regard to food threat and the lowering of production cost [2]. The use of non-edible oilseeds such as Azadirachta indica, Jatropha curcas, Jatropha gossipifolia, Calophhyllum inophyllum, Hura crepian, Chrystophyllum albidium, and Thevetia peruviana have been extensively discussed in the literature [31-35]. Although some of these oils are characterized by high amounts of free fatty acid (FFA), they are an alternative for the cost reduction of the transesterification process. Oils characterized by high amounts of FFA can be esterified using an acid of a lower $\mathrm{pH}$ value $(\leq 1.5)$ before their transesterification by alkaline/heterogeneous base catalysts. When choosing calcinated potassium silicate oils characterized by high amounts of FFA, they can easily be converted without esterifying, but due to the high cost of potassium silicate, the first solution is better than the latter.

Homogeneous and heterogeneous catalysts have reportedly been applied to biodiesel production. Dhoot et al. produced biodiesel using a homogeneous alkali catalyst, whereas Ana et al. [36] have used a heterogeneous mixture of Hexane/Ether as a catalyst for producing biodiesel and Betiku et al. [37] a homogeneous catalyst for producing biodiesel from Sesamum indicum oil. A methanolysis of soybean oil with $1 \%$ potassium hydroxide as a catalyst has been carried out by Tomasevic et al., whereas Umer et al. have worked on the application of a response surface methodology for the optimization of the transesterification of Moringa oleifera oil applying a homogeneous catalyst, and Zhang et al. [38] have worked on the 
optimization of the transesterification reaction from cotton seed oil by means of a statistical approach using a homogeneous base catalyst. The major drawbacks of these types of catalysts are difficulties in their recovery from the reaction medium and attendant problems, in particular saponification, excess reactant consumption, environmental pollution, high oil/alcohol molar ratios, and extra costs for separation, which increase the overall costs of production [35]. Heterogeneous catalysts mainly involve the use of a solid base catalyst, which can easily be separated from the transesterified product, and is always active at the boiling point temperature of methanol during transesterification [39]. In support of this claim, Choi [40] reported that the heterogeneous catalyst is recoverable, less corrosive, produces no soap, and can be reused. Therefore, researchers have tested varieties of solid base for the catalytic activity. For this purpose, Xie et al. [41] prepared potassium loaded on alumina as a solid base catalyst and employed it for the transesterification of soybean oil at reflux of methanol. Under the same conditions, they examined the solid base catalysis of magnesium-aluminum (Mg-Al) mixed oxide prepared by calcining the corresponding hydrotalcite. Interestingly, Shibasaki-Kitagawa et al. [42] have explained the anion-exchange resin catalyzed through a transesterification of triolein, which is a model of vegetable oil. In the same vein, Deka [43] have used M. balbisiana as a heterogeneous catalyst for the production of biodiesel from yellow oleander. Several studies described in $[35,44,45]$ have also examined the use of different heterogeneous catalysts in the production of biodiesel with or without optimizing the process conditions.

Minitab is a statistical analysis software package that provides a wide range of data analysis options and has been used in optimization conversion of sunflower oil to biodiesel using sodium methoxide. Data analysis was performed through response surface methodology (RSM) and by using Minitab v.14, statistical package [45]. Yan [46] developed linear and full quadratic regression models using Minitab version 16 software, both to predict FFA and FAME concentration and to optimize the reaction conditions of biodiesel production from Calophyllum inophyllum oil. In the same vein, biodiesel production from Scenedesmus $s p$. through optimized in situ acid in a transesterification process has been carried out by Xie [40]. The study used Minitab RSM version 16 to examine the process analysis. The advantages of this software over others include accessibility, strength in statistical quality control, descriptive and inferential statistics, statistical process control (SPC), reliability, gage repeatability and reproducibility (GR\&R) studies, process capability, and better graphing output [47].

Artificial neural network (ANN) is a learning system based on a computational technique, which shows a non-linear relationship between connecting factors and actual responses by means of iterative training of data obtained from a designed experiment [48]. ANNs show superiority as a modeling technique for data sets, data fitting, and prediction abilities [48, 49], which has also been applied in various professional fields of engineering, health, and sciences [50]. An early report presented in [51] ANN was applied to determine diesel engine performance and exhaust emission analysis using waste cooking biodiesel fuel. The use of ANN for the prediction of the cetane number of biodiesel has been presented in [52]. Furthermore, a based prediction of performance and emission characteristics of a variable compression ratio $\mathrm{CI}$ engine, using $\mathrm{WCO}$ as a biodiesel at different injection times by means of ANN was examined by Shivakumara et al. [53], whereas Najafi et al. [54] have applied ANN in the performance and exhaust emissions of a biodiesel engine, and Najafi [55] carried out a combustion analysis of a CI Engine Performance employing waste cooking biodiesel fuel with an ANN Aid. Another application includes not only biodiesel production from soybean oil [56] and waste frying palm oil [57], but also the prediction of engine performance for an alternative fuel [58] and the simulation of biodiesel production from waste olive oil [59].

Therefore, the aim of this study is to exploit the use of calcinated BPSM for biodiesel production from Thevetia peruviana (T. peruviana) in a two-step conversion. To determine the significance of the variables for the processes, minitab response surface and artificial neural network will be used for modeling and optimizing the process variables. The fuel properties of $T$. peruviana biodiesel will also be evaluated with the objective of determining its potential use.

\section{Methods \\ Materials \\ Method for the extraction of T. peruviana powder oil}

Matured oilseeds of $T$. peruviana were collected from the Ogbo Grammar School, Omu-Aran, Kwara State, Nigeria. The greenish fleshy pericarps were removed manually, while the hard brownish mesocarp with the seeds was sun-dried to constant weight. The kernel fruit was shelled and sun-dried until constant weight. Separation of chaff from the kernel fruit was carried out by winnowing. The cleaned kernel fruit was then milled into powder (T. peruviana oilseed powder) and kept in a clean container for further processing.

The BPSM used was obtained from the Landmark University, Omu-Aran, Kwara State, Nigeria. The BPSM was not only washed in distilled water to remove dirt, but also sun-dried to constant weight before grounding to a particle size of $5 \mathrm{~mm}$ (to ensure a large surface area per unit mass), and stored in a clean crucible for further processing. The necessary chemicals hexane, ethanol, Wij's solution, diethyl ether, chloroform, and others were purchased from Isolak Nig. Ltd. and were of "organic trace analysis" grade. 


\section{Methods}

Method for the extraction of T. peruviana powder oil A known weight of $T$. peruviana oilseed powder was placed in a muslin cloth, and analytical grade n-hexane was employed as a solvent for extraction. According to optimization software, 15 experimental runs were generated and carried out in a 4-faced heating mantle capable of holding $500 \mathrm{ml}$ capacity Soxhlet extractors. Excess n-hexane in the oil was recovered using a "rotavaps" (rotary evaporator), and the percentage yield of oil produced was calculated based on the ratio of weight oil extracted to that of the weight of T. peruviana powder used (Eq. 1).

$$
\begin{aligned}
& \text { T.peruviana oil yield }(\%) \\
& =\frac{\text { weight of T.peruviana seedoil }}{\text { weight T.peruviana oilseed powder }} \\
& \quad \times 100
\end{aligned}
$$

\section{Experimental design of oil extraction from $T$. peruviana oilseed powder}

In order to model and optimize the extraction of oil from T. peruviana powder, minitab response surface (MRS) version 15.5 was employed to generate 15 experimental runs. The influence of extraction time: $X_{1}$, solvent volume: $X_{2}$ and sample weight: $X_{3}$ were considered (Table 1). The experimental runs were randomized to minimize the effects of unexpected variability in the observed responses, and the process was described using a second order model. To relate the response variable to the independent variables, multiple regressions were introduced to fit the coefficient of the second-order quadratic polynomial model of the response. The fit of the model was evaluated using a test of significance and ANOVA analysis.

\section{The properties of extracted T. peruviana seed oil}

The properties of the extracted oil were evaluated based on physical, chemical, and other properties employing standard methods (AOAC 1997) and Wij's method.

\section{Gas chromatographic mass spectrometric (GC-MS) analysis of $T$. peruviana seed oil}

To ascertain the compositions of free fatty acid present in the oil, a gas chromatographic mass spectrometer (Agilent 19091S-433HP-5MS) was employed. The operating conditions of the equipment were as follows: Column Elite-1 fused silica capillary column (30 $\mathrm{mm} \times 250 \mu \mathrm{m} \times 0.25 \mu \mathrm{m}$, composed of $5 \%$ phenyl methyl silox), operating in an electron multiplier volts $1329.412 \mathrm{eV}$, Helium (99.99\%) was applied as a carrier gas at a constant flow of $1.5 \mathrm{ml} / \mathrm{min}$, and an injection volume of $1 \mu \mathrm{l}$ was employed (split ratio of 10:1), at an injector temperature of $150{ }^{\circ} \mathrm{C}$ and an Ion-source temperature of $250{ }^{\circ} \mathrm{C}$. The oven temperature was programmed from $35{ }^{\circ} \mathrm{C}$ (isothermal for $5 \mathrm{~min}$.), at an increase of $4{ }^{\circ} \mathrm{C} / \mathrm{min}$ to $150{ }^{\circ} \mathrm{C}$, for $2 \mathrm{~min}$, then at $20^{\circ} \mathrm{C} / \mathrm{min}$ to $250{ }^{\circ} \mathrm{C}$, for $5 \mathrm{~min}$ (isothermal at $250{ }^{\circ} \mathrm{C}$ ). The mass spectra were taken at an average velocity of $44.297 \mathrm{~cm} / \mathrm{s}$ at a hold up time of $1.1287 \mathrm{~min}$, a pressure of $11.604 \mathrm{psia}$ and a frequency of $50 \mathrm{~Hz}$ with a total GC running time of $45 \mathrm{~min}$.

\section{Catalyst calcination and elemental characterization}

Eight samples, each weighing $50 \mathrm{~g}$ of grounded BPSM were prepared. Four samples were soaked in methanol for $10 \mathrm{~min}$ and were stirred before filtering, while the remaining four samples were not soaked. The eight samples were calcinated in a Carbolite AAF 1100 furnace at $700{ }^{\circ} \mathrm{C}$ for $4,5,6$, and $7 \mathrm{~h}$, respectively. To identify the calcinated BPSM with the highest base catalyst, elemental analysis of the calcinated samples was performed using an EDXRF Spectrophotometer (EDX3600B). The EDXRF spectrophotometer was calibrated according to the recommended silver standard, while the analysis was carried out using the ore standard calibration curve. The calcinated BPSM identified with the highest base catalyst was used for the second-stage transesterification process.

\section{The production of seed oil biodiesel by $T$. peruviana}

The initial acid value of $T$. peruviana seed oil amounted to 3.8048, corresponding to an FFA level of 1.9024, which was above the limit for a satisfactory transesterification. Hence, a reduction in the acid value via an acid-catalyzed esterification process was required.

\section{Acid-catalyzed esterification process}

An acid-catalyzed esterification process was carried out according to the modified method adopted by [35]. $75 \mathrm{ml}$ of $T$. peruviana seed oil were measured

\begin{tabular}{|c|c|c|c|c|}
\hline \multirow[t]{2}{*}{ Variable } & \multirow[t]{2}{*}{ Symbol } & \multicolumn{3}{|c|}{ Coded factor levels } \\
\hline & & -1 & 0 & +1 \\
\hline Extraction time (min) & $x_{1}$ & 40 & 50 & 60 \\
\hline Solvent volume (ml) & $x_{2}$ & 200 & 225 & 250 \\
\hline Sample weight (g) & $x_{3}$ & 40 & 45 & 50 \\
\hline
\end{tabular}
and then were filled into a $250 \mathrm{ml}$ glass reactor for

Table 1 Variables factors considered for T. peruviana oil extraction 
heating to $60{ }^{\circ} \mathrm{C}$ on a hot plate using a magnetic stirrer for preheating, and mixing a known volume of acid $\left(\mathrm{H}_{2} \mathrm{SO}_{4}\right)$ with a known volume of an analytical grade methanol. After this, the mixture was added to the pre-heated oil in the reactor and was allowed to stir continuously for $1 \mathrm{~h}$. The esterified oil was then transferred into a separating funnel to stand for $2 \mathrm{~h}$. The methanol-water layer formed on the bottom of the separating funnel was tapped. Excess methanol in the oil was evaporated prior to the determination of the acid value. This process was repeated regularly under different conditions until the minimum acid

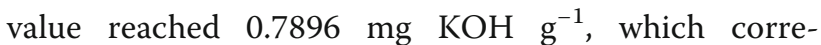
sponded to $\mathrm{FFA}=0.3948 \mathrm{mg} \mathrm{KOH} \mathrm{\textrm {g } ^ { - 1 }}$ before the transesterification process.

\section{Base-catalyzed transesterification of esterified oil}

The base-catalyzed transesterification of esterified oil was carried out according to the modified method of [60]. Hence, the transesterification procedure of $T$. peruviana seed oil was performed, as requested. A known volume of esterified T. peruviana seed oil with the lowest acid value was measured and introduced into a 250-ml-necked reactor with a magnetic stirrer, where it was placed on a hot plate, and charged with a known weight of base catalyst dissolved in a known volume of anhydrous methanol. Two layers were observed, and the reactor flask was covered by the stopper to prevent the methanol from escaping, as the reaction proceeded. The hot plate temperature regulator was then adjusted to $60{ }^{\circ} \mathrm{C}$ to complete the reaction at a known time. At the end of the reaction, the resulting products were transferred to a separating funnel for glycerol (denser) and biodiesel (less dense) gravity settling $(24 \mathrm{~h})$. Glycerol was tapped off from the bottom of the separating funnel leaving behind the less dense biodiesel in the funnel. Meanwhile, the clarity of the biodiesel has significant effects on its fuel properties. The biodiesel left in the funnel was then washed until the distilled water became clear, in such a way allowing the residual catalyst, untapped glycerol, methanol, and soap to be removed. The washed T. peruviana biodiesel was then tapped into a pyrex flask, where it was further dried over heated $\mathrm{CaCl}_{3}$. After this, the dried biodiesel was purified by filtration, and the final $T$. peruviana biodiesel was calculated in terms of \% $(v / v)$, as presented in Eq. (2). This experiment was repeated for 15 runs as had been modeled by design software.

$$
\begin{aligned}
& \text { T.peruviana biodiesel yield } \%(v / v) \\
& =\frac{\text { Volume of T.peruviana biodiesel }}{\text { Volume of esterified T.peruviana oil }}
\end{aligned}
$$

\section{Experimental design for the transesterification of esterified $T$. peruviana oil}

To optimize the transesterification of esterified $T$. peruviana oil, the minitab response surface (MRS) version 15.5 was used to generate 15 experimental runs. The factors selected for the transesterification process were methanol/oil ratio: $X_{1}$, reaction time (min): $X_{2}$, and catalyst amount $(\mathrm{g}): X_{3}$ (Table 2). The experimental runs were randomized to minimize the effects of unexpected variability in the observed responses. The process was described by the second order method employed. To relate the response variable to the independent variables, multiple regressions were used to fit the coefficient of the second-order quadratic polynomial model of the response. The quality of the fit of the model was evaluated using both a test of significance and ANOVA analysis.

\section{Properties of $T$. peruviana biodiesel}

It is necessary to determine the properties of the biodiesel produced from the $T$. peruviana seed oil to ascertain its suitability for running an internal combustion engine (IC engine). These properties include, among others, the specific gravity, kinematic viscosity, moisture content, peroxide value (PV), saponification value (SV), and iodine value (IV).

\section{Fuel properties of biodiesel}

The fuel properties of the produced biodiesel, such as cetane number $(\mathrm{CN})$, higher heating value $(\mathrm{HHV})$, API value, diesel index, and aniline point, were computed applying the standard Eqs. (3-7) according to American Society of Testing and Material (ASTM) D2015.

\begin{tabular}{|c|c|c|c|c|}
\hline \multirow[t]{2}{*}{ Variable } & \multirow[t]{2}{*}{ Symbol } & \multicolumn{3}{|c|}{ Coded factor levels } \\
\hline & & $\overline{-1}$ & 0 & +1 \\
\hline Catalyst amount (g) & $\mathrm{X} 1$ & 2.00 & 4.00 & 6.00 \\
\hline Reaction time (min) & $\times 2$ & 50 & 60 & 70 \\
\hline Methanol/oil ratio (v/v) & $\mathrm{X} 3$ & 0.10 & 0.15 & 0.20 \\
\hline
\end{tabular}

Table 2 Variables factors considered for transesterification of T. peruviana oil to biodiesel 


$$
\begin{array}{r}
\text { Cetane no. }=46.3+\frac{5458}{\text { Saponification value }} \\
-0.225 \text { Iodine value }
\end{array}
$$

HHV $(M J / k g)=49.43-[0.041$ (Saponification value) +0.015 (Iodine value)]

$A P I=\frac{141.5}{\text { Specific gravity@15 }{ }^{\circ} \mathrm{C}}-131.5$

Diesel index $=\frac{\text { Cetane number }-10}{0.72}$

Aniline point $=\frac{\text { Diesel index } \times 100}{A P I}$

\section{Statistical data analysis}

The data obtained from the T. peruviana oilseed extraction experiment and the transesterification of biodiesel were analyzed statistically using MRS version 15.5 and ANN, a Neural Power version 2.5 (CPC-X Software), in order to fit the quadratic polynomial equation. To correlate the response variable to the independent variables, multiple regressions were used to accommodate the coefficient of the polynomial model of the response. The quality of the fit to the model was evaluated using TS (test of significance) and ANOVA (analysis of variance). A statistical analysis was performed by evaluating the regression model called determination coefficient $\left(R^{2}\right)$, root means square error (RSME) and plotted the $2 \mathrm{D}$ contour line as well as the 3D graph. The fitted quadratic response model equation is described in Eq. (8).

$$
\begin{aligned}
R_{F}= & \tau_{0}+\sum_{i=1}^{k} \tau_{i} X_{i}+\sum_{i=1}^{k} \tau_{i i} X_{i}^{2}+\sum_{i<j}^{k} \tau_{i j} X_{i} X_{j} \\
& +e
\end{aligned}
$$

where $R_{\mathrm{F}}$ denotes the response factor (T. peruviana seed oil/biodiesel).

$\tau_{0}$ represents the intercept value, $\tau_{\mathbf{i}}(i=1,2, k)$ the first order model coefficient, $\tau_{i j}$ the interaction effect, $\tau_{i i}$ the quadratic coefficients of $X_{\mathrm{i}}$, and $e$ is the random error.

\section{Results and discussion}

\section{Optimization of the extraction of $T$. peruviana seed oil}

The coded factors considered in this study are listed in Table 3 along with the experimental results, the predicted values, and the residual values obtained. Observations from Table 3 indicate that the highest experimental T. peruviana seed oil yield was $44.00 \%(w / w)$ at variable factors of $X_{1}=$ $60 \mathrm{~min}, X_{2}=225 \mathrm{ml}$, and $X_{3}=40 \mathrm{~g}$. The predicted re-

\begin{tabular}{|c|c|c|c|c|c|c|c|c|}
\hline \multirow{2}{*}{$\begin{array}{l}\text { Std } \\
\text { run }\end{array}$} & \multirow[t]{2}{*}{$X_{1}$} & \multirow[t]{2}{*}{$x_{2}$} & \multirow[t]{2}{*}{$x_{3}$} & \multirow{2}{*}{$\begin{array}{l}\text { Oil } \\
\text { yield\% } \\
(v / v)\end{array}$} & \multicolumn{2}{|c|}{ Predicted } & \multicolumn{2}{|c|}{ Residual } \\
\hline & & & & & MRS & ANN & MRS & ANN \\
\hline 1 & 0 & 0 & 0 & 28 & 27.38 & 27.33 & 0.62 & 0.67 \\
\hline 2 & 0 & 0 & 0 & 27 & 27.38 & 27.33 & -0.38 & 0.33 \\
\hline 3 & 0 & 1 & 1 & 27 & 26.96 & 27.01 & 0.04 & 0.01 \\
\hline 4 & 0 & -1 & 1 & 27 & 26.96 & 27.01 & 0.04 & 0.01 \\
\hline 5 & 1 & 0 & 1 & 33 & 33.04 & 32.97 & -0.04 & 0.03 \\
\hline 6 & -1 & 0 & 1 & 32 & 32.04 & 32.00 & -0.04 & 0.00 \\
\hline 7 & 0 & 0 & 0 & 27 & 27.38 & 27.33 & -0.38 & 0.33 \\
\hline 8 & -1 & -1 & 0 & 27 & 26.96 & 27.00 & 0.04 & 0.00 \\
\hline 9 & 1 & 1 & 0 & 39 & 38.96 & 39.02 & 0.04 & 0.02 \\
\hline 10 & 1 & -1 & 0 & 39 & 38.96 & 39.02 & 0.04 & 0.02 \\
\hline 11 & 1 & 0 & -1 & 44 & 44.04 & 43.95 & -0.04 & 0.05 \\
\hline 12 & 0 & 1 & -1 & 27 & 26.96 & 27.00 & 0.04 & 0.00 \\
\hline 13 & -1 & 1 & 0 & 27 & 26.96 & 27.00 & 0.04 & 0.00 \\
\hline 14 & -1 & 0 & -1 & 21 & 21.04 & 21.00 & -0.04 & 0.00 \\
\hline 15 & 0 & -1 & -1 & 27 & 26.96 & 27.01 & 0.04 & 0.01 \\
\hline
\end{tabular}
sponses for MRS and ANN were $44.04 \%(w / w)$ at variable
Table 3 Coded factors with experimental oil results, predicted and residual values by MRS and ANN for T. peruviana oilseed extraction

factors of $X_{1}=59.30 \mathrm{~min}, X_{2}=225 \mathrm{ml}$, and $X_{3}=39 \mathrm{~g}$ and $43.95 \%(w / w)$ at variable factors of $X_{1}=59.00 \mathrm{~min}, X_{2}=$ $220 \mathrm{ml}$, and $X_{3}=38.70 \mathrm{~g}$, respectively. The predicted values were validated by carrying out three experiments under the predicted variable conditions to obtain an average $T$. peruviana seed oil yield of $43.50 \%(w / w)$ and $43.80 \%(w / w)$ for MRS and ANN, respectively. Table 4 illustrates the results of the test of significance for each regression coefficient. The results showed that the $p$ values $\left(X_{1}, X_{3}\right),\left(X_{1} X_{3}\right)$, and $\left(X_{1}^{2}\right.$ and $\left.X_{3}^{2}\right)$ of the model terms were significant $(p<0.05)$. The model coefficients and probability values are shown in Table 5, whereas the analysis of variance of the regression equation model is shown in Table 6 . The mathematical expression of the relationship between T. peruviana seed oil and the variables considered is given in Eq. (9).

$$
\begin{aligned}
Y_{\text {Oil }} \%(w / w)= & -145.0-0.027 X_{1}+7.02 X_{3} \\
& +0.0558 X_{1}^{2}-0.01692 X_{3}^{2}-0.110 X_{1} X_{3}
\end{aligned}
$$

Table 4 Test of Significance for Regression Coefficient

\begin{tabular}{llllllll}
\hline Source & DF & Seq. SS & Contribution\% & Adj. SS & Adj. MS & F-Value & P-Value \\
\hline$X_{1}$ & 1 & 288.000 & 54.57 & 288.000 & 288.000 & 3744.00 & 0.000 \\
$X_{3}$ & 1 & 0.000 & 0.00 & 0.000 & 0.000 & 0.00 & 1.000 \\
$X_{1}{ }^{2}$ & 1 & 117.376 & 22.24 & 115.522 & 115.522 & 1501.79 & 0.000 \\
$X_{3}{ }^{2}$ & 1 & 0.665 & 0.13 & 0.665 & 0.665 & 8.64 & 0.016 \\
$X_{1} X_{3}$ & 1 & 121.000 & 22.93 & 121.000 & 121.000 & 1573.00 & 0.000
\end{tabular}

Where: DF Degree of Freedom, Seq. SS Sequential Sum of Square, Adj. SS Adjusted Sum of Square, Adj. MS Adjusted Mean Square, F Fischer, $P$ Probability 
Table 5 Analysis of Variance (ANOVA) of Regression Equation

\begin{tabular}{llllllll}
\hline Source & DF & Seq. SS & Contribution\% & Adj. SS & Adj. MS & F-Value & P-Value \\
\hline Model & 5 & 527.041 & 99.87 & 527.041 & 105.408 & 1370.31 & 0.00 \\
Lack-of-Fit & 7 & 0.026 & 0.00 & 0.026 & 0.004 & 0.01 & 1.00 \\
Pure Error & 2 & 0.667 & 0.13 & 0.667 & 0.333 & \\
Total & 14 & 527.733 & 100.00 & & \\
& \multicolumn{7}{c}{$R^{2}=99.87 \%, R^{2}$ (adjusted) $=99.80 \%, R^{2}$ (predicted) $=99.77 \%$} \\
\hline
\end{tabular}

Where: DF Degree of Freedom, Seq. SS Sequential Sum of Square, Adj. SS Adjusted Sum of Square, Adj. MS Adjusted Mean Square, F Fischer, P Probability

The significance of regression was evaluated by the $F$ value and the $p$ values using Fischer's and null-hypothesis tests; where the $F$ value predicts the quality of the entire model considering all design factors at a time, whereas the $p$ value denotes the probability of the factors having very little or insignificant effect on the response. A higher $F$ value signifies a better fit of the RSM model to the experimental data [61]. According to [62], an $F$ value along with low $p$ value indicates a high significance of the regression model. Nevertheless, the $p$ value should be lower than 0.05 for the model to be statistically significant [63]. Based on these reports, the regression model found in this study was highly significant, as is evident by the large $F$ value = 1370.31 and the low $p$ values $=0.000$, respectively.

To test the fit of the model equation, the regression model was established using $R^{2}$ as a measure of how much variability in the observed response values can be explained by the experimental factors and their interactions [64]. The $R^{2}$ value is always between 0 and $1[37,65]$. However, for creating a good-fit model, it was recommended that $R^{2}$ should not be less than $80 \%$ [66]. The results in Table 7 indicate an $R^{2}$ value of $99.87 \%$ which leaves only $0.13 \%$ of the variability in the observed response values to be not explainable by the model and indicates that an unexplainable total variation could be caused by other factors, which were not included in the model.

The graphical depiction provides a method to visualize the relationship between the response and the experimental levels of each variable on the one side, and the type of interactions between the test variables, on the other, which allows for deducing the optimum conditions. The contour and surface plots for oil extraction from T. peruviana seed oil under the feasible optimum conditions for Minitab
RSM and ANN are shown in Fig. 1a-f A plot of the linear correlation between the experimental yields and the predicted value for oil extraction by ANN is presented in Fig. 2, indicating that the models are adequate without any violation of independence or constant assumption. The accuracy of the models obtained from MINITAB RSM and ANN was determined by comparing the values of $R^{2}$. The result depicts that both optimization tools allowed good predictions to be achieved due to the value of $R^{2}$ (of 99.870 and $99.936 \%$ for RSM and ANN, respectively). Therefore, for the extraction of $T$. peruviana oilseed, ANN showed a clear superiority over Minitab RSM due to the $R^{2}$ value and the predicted optimum yield.

\section{Properties of the $T$. peruviana seed oil}

The properties of the $T$. peruviana seed oil were determined according to the standard methods, and the results are shown in Table 7. The oil obtained was liquid, yellowish in color with a moisture content of $0.0131 \%$ and a specific gravity of $0.8984 \mathrm{~g} / \mathrm{cm}^{3}$, at a density of $0.774 \mathrm{~g} / \mathrm{cm}^{3}$. The obtained acid and FFA values of 3.8048 and 1.9024 point to a good resistance of the oil to hydrolysis, whereby the abovementioned values are in close agreement with the results obtained by other researchers. The peroxide value measures the content of hydroperoxides in the oil [67], and its low value (23.8 meq. $\mathrm{O}_{2} / \mathrm{kg}$ ) indicated a high resistance to oxidation. A high saponification value of $157.5025 \mathrm{mg} \mathrm{KOH} / \mathrm{g}$ and an iodine value of $97.60 \mathrm{gI}_{2} / 100 \mathrm{~g}$ pointed to both a low concentration of triglycerides and an oil containing a substantial level of unsaturation. The high HHV $(57.612 \mathrm{MJ} / \mathrm{kg})$ was associated with the latent heat of

Table 6 Regression coefficients and significance of response surface quadratic

\begin{tabular}{|c|c|c|c|c|c|c|c|c|}
\hline Term & Effect & Coefficient & Standard Error Coefficient & $\begin{array}{l}95 \% \mathrm{Cl} \\
\text { Low }\end{array}$ & $\begin{array}{l}95 \% \mathrm{Cl} \\
\mathrm{High}\end{array}$ & P-Value & T-Value & $\mathrm{VIF}$ \\
\hline Constant & - & 27.385 & 0.1330 & 27.083 & 27.686 & 0.000 & 205.54 & - \\
\hline$x_{1}$ & 12.000 & 6.000 & 0.0981 & 5.7782 & 6.2218 & 0.000 & 61.19 & 1.00 \\
\hline$x_{3}$ & 0.000 & 0.000 & 0.0981 & -0.2218 & 0.2218 & 1.000 & 0.00 & 1.00 \\
\hline$x_{1}^{2}$ & 11.154 & 5.577 & 0.1440 & 5.251 & 5.902 & 0.000 & 38.75 & 1.01 \\
\hline$x_{3}^{2}$ & -0.846 & -0.423 & 0.1440 & -0.749 & -0.098 & 0.016 & -2.94 & 1.01 \\
\hline$x_{1} x_{3}$ & -11.000 & -5.500 & 0.1390 & -5.814 & -5.186 & 0.000 & -39.66 & 1.00 \\
\hline
\end{tabular}


Table 7 Physical, Chemical and Other properties of T. peruviana seedoil extracted

\begin{tabular}{ll}
\hline Parameters & Yellow oleander seed oil \\
\hline Physical properties & \\
Physical state at room temperature & Yellowish in colour \\
Moisture content (\%) & 0.0131 \\
Specific gravity & 0.8984 \\
Mean Molecular mass & 973.87 \\
Chemical properties & \\
\%FFA (as oleic acid) & 1.9024 \\
Acid value (mg KOH/g oil) & 3.8048 \\
Saponification value (mg KOH/g oil) & 57.5025 \\
lodine value ( $\mathrm{g} \mathrm{I} / 100 \mathrm{~g}$ oil) & 97.600 \\
Peroxide value (meq $\mathrm{O}_{2} / \mathrm{kg}$ oil) & 23.800 \\
Higher heating value $(\mathrm{MJ} / \mathrm{kg})$ & 47.056 \\
Other properties & \\
Cetane number & 140.998 \\
API & 26.00 \\
Diesel index & 181.94 \\
Aniline point ( $\left.{ }^{\circ} \mathrm{F}\right)$ & 699.77 \\
\hline
\end{tabular}

vaporization of water in the combustion products. Both fuel properties and cetane number $(\mathrm{CN})$ are not only a measure of the fuel's ignition delay and combustion quality, but also of its biodiesel standard with a minimum of 40 [68, 69] BIS HIE. The high value (58.99) obtained in this study shows that the oil has high fuel potential. The API and diesel index of T. peruviana seed oil was less than that of AGO but are comparable with other vegetable oils earlier reported by [70, 71].

\section{Gas chromatographic analysis of $T$. peruviana seed oil}

GC-MS is one of the techniques which allows for the identification of the constituents of volatile matter, long and branched chain hydrocarbons, alcoholic acids, esters and other components [72]. The results pertaining to the analysis leaded to the identification of the number of compounds from the GC fractions of $T$. peruviana seed oil. The analysis had proved that the oil contained linoleic $(37.91 \%)$, oleic $(32.82 \%)$, linolenic $(12.33 \%)$, palmitic $(9.52 \%)$, stearic $(7.02 \%)$, and other $(0.40 \%)$ acids. It was observed that it also contained a substantial level of unsaturation (70.73\%), which implies a low saponification value and a high iodine value (Table 8 ).

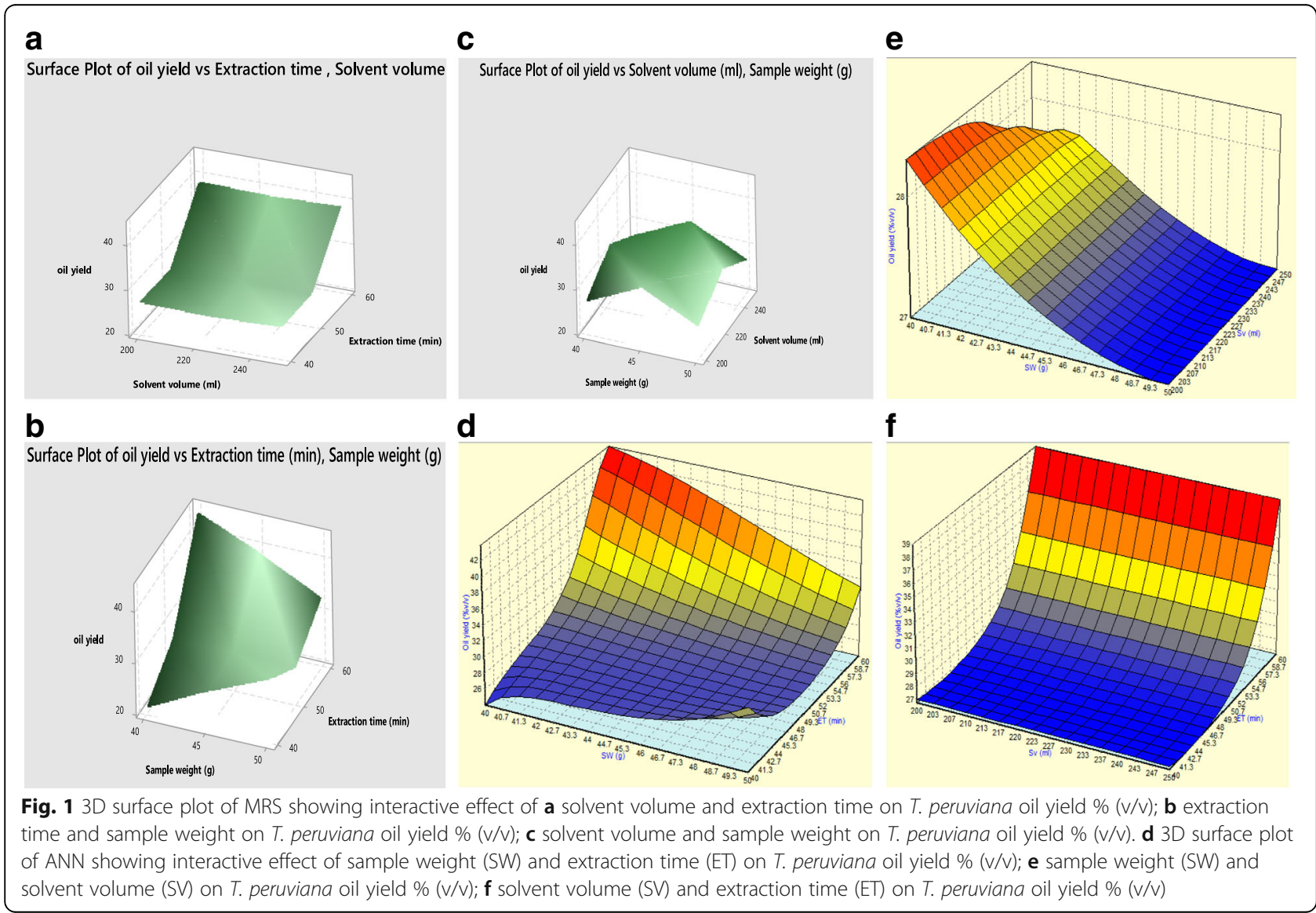




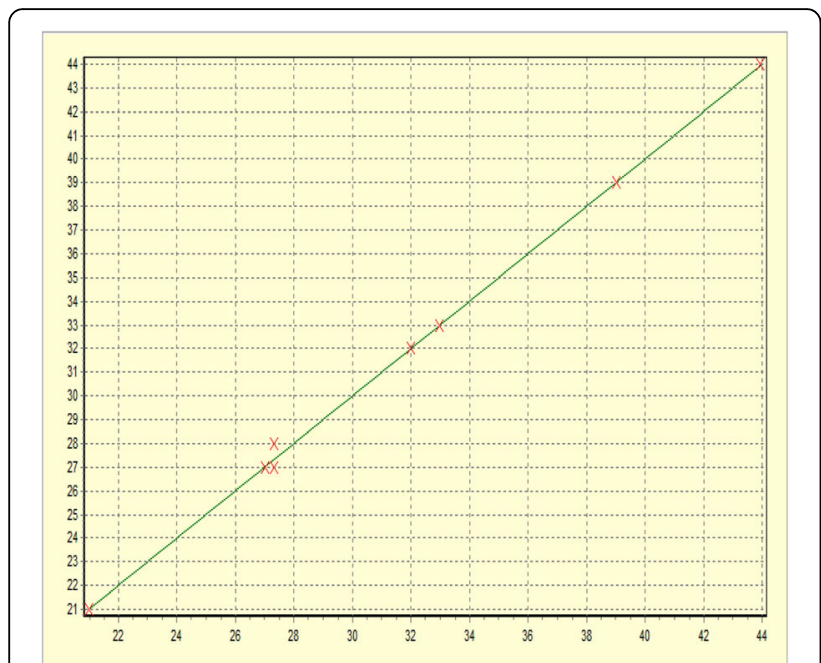

Fig. 2 Linear correlation between oil yield \%(v/v) (vertical axis) and ANN value \%(v/v) (horizontal)

\section{EDXRF catalyst composition analysis}

Table 9 demonstrates the results of the elemental analysis using an EDXRF spectrophotometer (EDX3600B) for the calcinated grounded BPSM samples A, B, C, D, E, F, G, and $\mathrm{H}$ in a furnace at $700{ }^{\circ} \mathrm{C}$. Samples A, D, E, and $\mathrm{H}$ were pre-soaked in methanol for $10 \mathrm{~min}$, while samples B, C, F, and G were not pre-soaked. Samples A and $B$ were calcinated for $4 \mathrm{~h}$, samples $\mathrm{C}$ and $\mathrm{D}$ for $5 \mathrm{~h}$, samples $\mathrm{E}$ and $\mathrm{F}$ for $6 \mathrm{~h}$, and samples $\mathrm{G}$ and $\mathrm{H}$ for $7 \mathrm{~h}$, respectively. From Table 9 and Fig. 3 (the corresponding spectrum), it was evident that sample D had the highest base content of $58.48 \%$, while sample B had the lowest amount of base at $54.73 \%$. Therefore, pre-soaking pulverized BPSM in methanol and its calcination increased the elemental composition of base present in the sample.

\section{Esterification process catalyzed $T$. peruviana seed oil acid}

Table 10 presents the esterification conditions along with their corresponding acid and FFA values. The optimum condition obtained for the pre-treatment of

Table 8 Percentage prevailing compound from gas chromatography analysis of T. peruviana oil

\begin{tabular}{lll}
\hline S/N & Acids Compounds & Percentage (\%) \\
\hline 1 & Linoleic & 37.91 \\
2 & Oleic & 32.82 \\
3 & Linolenic & 12.33 \\
4 & Palmitic & 9.52 \\
5 & Stearic & 7.02 \\
6 & Other & 0.40 \\
& Total & 100 \\
7 & Unsaturation & 70.73 \\
8 & Saturation & 28.87 \\
\hline
\end{tabular}

$75.00 \mathrm{ml}$ of $T$. peruviana seed oil was established at a methanol/acid volumetric ratio of $12 \mathrm{ml}$ and a methanol volume of $75 \mathrm{ml}$; the acid value obtained under these conditions was $0.7896 \mathrm{mg} \mathrm{KOHg}^{-1}$ with a corresponding FFA value of $0.3948 \mathrm{mg} \mathrm{KOHg}^{-1}$ that was required for a successful transesterification of oil to biodiesel $[35,73]$.

\section{Transesterification process catalyzed by $T$. peruviana seed} oil base

Table 11 illustrates the coded factors, the experimental results, the predicted values, as well as the residual values obtained for both MRS and ANN. The maximum obtained experimental $T$. peruviana biodiesel yield reached $86.00 \%$ $(v / v)$ at a catalyst amount of $4 \mathrm{~g}: X_{1}$, a reaction time of 70 min: $X_{2}$ and a methanol/oil ratio of $0.1: X_{3}$. The optimum predicted yield achieved via MRS was $86.40 \%(\mathrm{v} /$ $v$ ) at a catalyst amount of $3.8 \mathrm{~g}: X_{1}$, a reaction time of 69 min: a $X_{2}$ and methanol/oil ratio of 0.11: $X_{3}$; ANN also predicted the optimum value of $86.80 \%(v / v)$ at a catalyst amount of $3.79 \mathrm{~g}: X_{1}$, a reaction time of $68.50 \mathrm{~min}$ : and $X_{2}$ a methanol/oil ratio of $0.10: X_{3}$. These predicted yields were validated by carrying out three experiments, and average yields of $85.70 \%(v / v)$ and $85.98 \%(v / v)$ were obtained for MRS and ANN, respectively. Table 12 listed the results of the test of significance for every regression coefficient. The results indicated that the $p$ values $(p<0.05)$ of the model terms were significant. Considering this case, $X_{1}, X_{2}, X_{3}, X_{2}^{2}$, and $X_{3}^{2}$ of linear and quadratic terms were found to be significant at a $95 \%$ confidence level. However, with reference to the large $F$ values and the corresponding low $p$ values, the catalyst amount $X_{1}(F$ value $=13,467.00)$ was the most significant variable followed by the methanol/oil ratio: $X_{3}(F$ value $=4563.00)$ followed by the reaction time: $\mathrm{X}_{2}(F$ value $=108.00)$; however, the quadratic term $X_{3}{ }^{2}$ with the $F$ value $=11,215.38$ was more significant than $X_{2}^{2}$ with an $F$ value $=10,722.46$. To minimize the error, all the coefficients were taken into consideration in the design. The ANOVA of regression is represented in Table 13. The model $F$ value $=$ 4835.25 with a low $p<0.0001$ implied a high significance for the regression model [74]. The final equation in terms of the coded factors for the MRS quadratic model is expressed by Eq. (10).

$$
\begin{aligned}
Y \%(v / v)= & 581.63-5.438 X_{1}-13.100 X_{2}-1417.5 X_{3} \\
& +0.0625 X_{1}^{2}+0.11000 X_{2}^{2} \\
& +4500.0 X_{3}^{2} \\
& +0.01250 X_{1} X_{2}-0.500 X_{2} X_{3}
\end{aligned}
$$

All the linear terms $\left(X_{1}, X_{2}, X_{3}\right)$ and cross-product terms $\left(X_{2} X_{3}\right)$ had negative effects on the $T$. peruviana biodiesel yield $(Y)$, while the cross-product term $\left(X_{1} X_{2}\right)$ 
Table 9: Results of calcinated samples analysis using EDXRF Spectrophotometer

\begin{tabular}{lllllllll}
\hline Calcinated samples & $\mathrm{A}_{\text {(pre-soaked) }}$ & $\mathrm{B}$ & $\mathrm{C}$ & $\mathrm{D}_{\text {(pre-soaked) }}$ & $\mathrm{E}_{\text {(pre-soaked) }}$ & $\mathrm{F}$ & $\mathrm{G}$ & $\mathrm{H}_{\text {(pre-soaked) }}$ \\
\hline Duration (hrs) & 4 & 4 & 5 & 5 & 6 & 6 & 7 & 7 \\
\% Potassium & 56.19 & 54.73 & 58.14 & 58.48 & 56.94 & 57.89 & 55.16 & 56.08
\end{tabular}

and all surface quadratic $\left(X_{1}^{2}, X_{2}^{2}, X_{3}^{2}\right)$ model terms had positive effects on the $T$. peruviana biodiesel yield. The ANOVA results of the regression equation are presented in Table 14. The significance of each coefficient in the experimental model was also determined by $T$ value and
$P$ value. A high $T$ test value and a low $P$ value indicate a high significance $[75,76]$. Student's $t$ test of each coefficient of the model showed that the linear coefficient $\left(X_{2}\right)$, the quadratic term $\left(X_{1}{ }^{2}, X_{2}{ }^{2}, X_{3}{ }^{2}\right)$ and the cross product $\left(X_{1} X_{2}\right)$ have significant effects $(P>|T|<0.05)$ on a

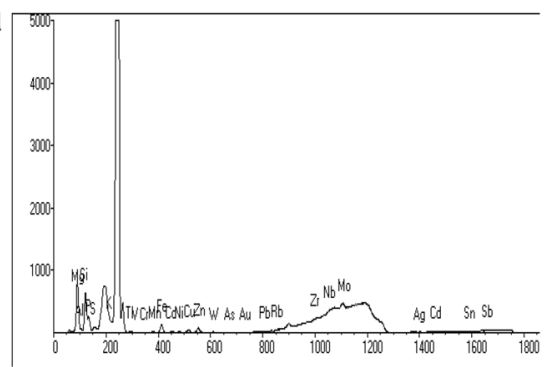

C

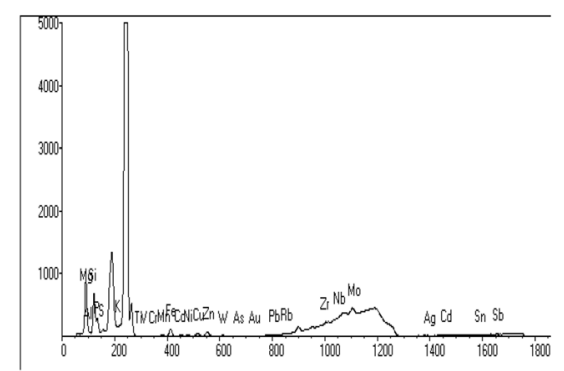

e

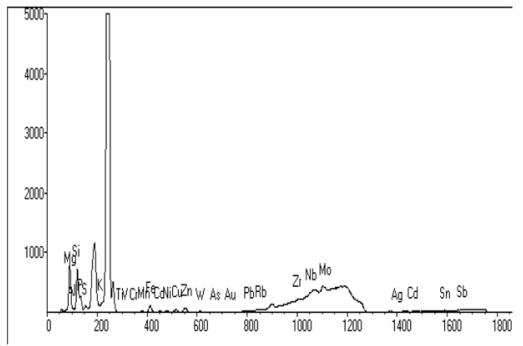

g

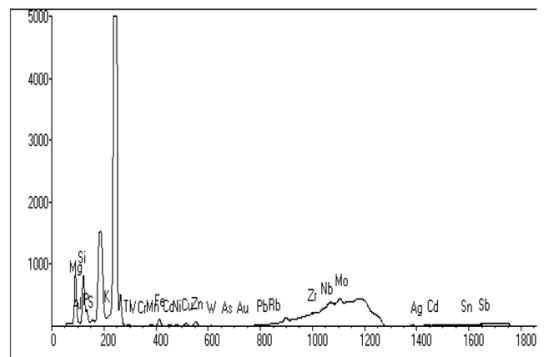

b

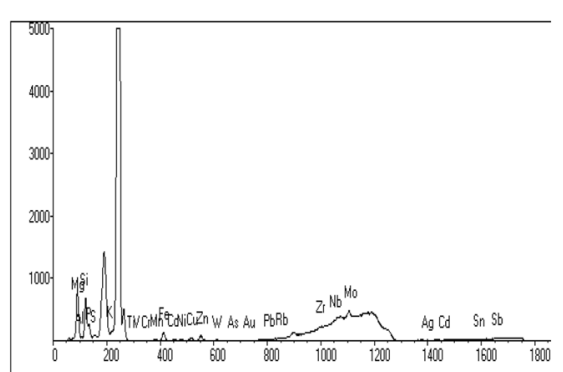

d

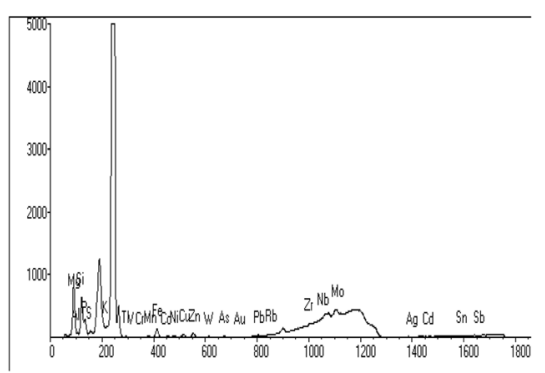

f

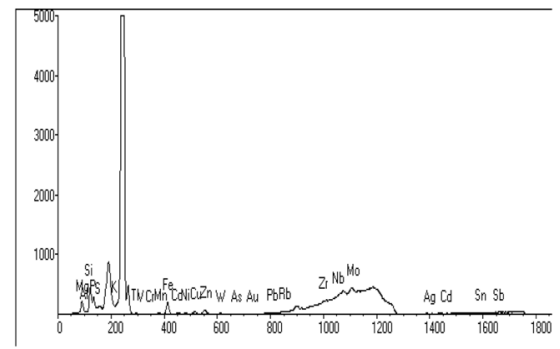

h

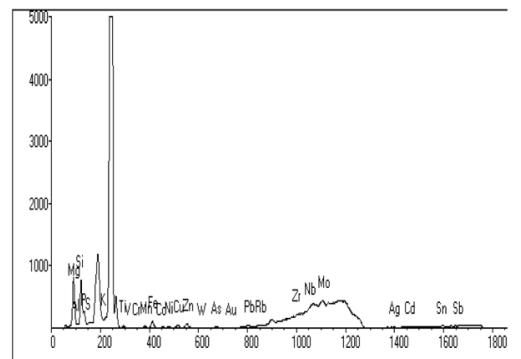

Fig. 3 a-h EDXRF Spectrophotometer spectrum curves for catalyst samples 
Table 10 Esterification condition with corresponding Acid and FFA values

\begin{tabular}{lll}
\hline Methanol/acid volume ratio & Acid value $\left(\mathrm{mgKOHg}^{-1}\right)$ & FFA $\left(\mathrm{mgKOHg}^{-1}\right)$ \\
\hline- & 3.8048 & 1.9024 \\
3.00 & 2.6920 & 1.8460 \\
6.00 & 2.2792 & 1.1396 \\
9.00 & 1.3536 & 0.6768 \\
12.00 & 0.7896 & 0.3948 \\
\hline
\end{tabular}

T. peruviana biodiesel (Y). All other terms displayed are not significant. The low values of standard error observed in the intercept and all the model terms demonstrated that the regression model fit the data, and the prediction was good [37]. The variance inflation factor (VIF) obtained in this study illustrates that the centre points are orthogonal to all other factors in the model.

The 3D surface plots are graphical representations of the regression equation for the optimization of the reaction variables, and they are presented in Fig. 4a-f. The curvatures' nature as plotted by MRS of the two- and three-dimensional surfaces in Fig. 4a-c shows an interactive effect among the variable selected and $T$. peruviana biodiesel yield. Furthermore, the curvatures' nature of the three-dimensional surfaces as plotted by ANN (Fig. 4d-f) suggested mutual interaction among the selected variables. The importance level of the selected variables considered for T. peruviana biodiesel by ANN is illustrated in Fig. 5, and it was evident that catalyst amount $X_{1}$ was the most important variable factor
(53.54\%) followed by methanol/oil ratio (41.31\%) and reaction time (5.15\%), respectively.

Furthermore, the accuracy of the models achieved by MRS and ANN based on $R^{2}$ was evaluated. The results depict that both optimization tools gave good predictions of $R^{2}$ (MRS: $R^{2}=99.98 \%$ and $\mathrm{ANN}: R^{2}=99.97 \%$ ).

\section{Effects of T. peruviana oilseed (feedstock) on the properties of biodiesel}

From the results, it was observed that $T$. peruviana seed is rich in oil, and its properties such as the low moisture content, the specific gravity, the diesel index, the cetane number, and the higher heating value make it suitable for biodiesel production. Furthermore, the high free fatty acid inherent in the oil points to its non-edibility and high unsaturation. Hence, the oil from T. peruviana seed is a good feedstock for environmental friendly biodiesel production.

\section{Effects of the catalyst (BPSM) on the properties of biodiesel production}

The results of an elemental analysis using an EDXRF spectrophotometer (EDX3600B) for calcined BPSM reveal that sample $\mathrm{D}$ has the highest base content of $58.48 \%$ (Table 9). Fig. 3a-h shows the corresponding spectrum with the relative abundance of the elements present. It was observed that various metals both in micro and in macro found in the calcinated sample, ranged from magnesium $(\mathrm{Mg})$ to antimony $(\mathrm{Sb})$. However, potassium demonstrated the highest relative abundance in

Table 11 Coded experimental design results, T. peruviana biodiesel yield, predicted values by MRS and ANN and the residual values for the transesterification process

\begin{tabular}{|c|c|c|c|c|c|c|c|c|}
\hline \multirow[t]{2}{*}{ Run } & \multirow[t]{2}{*}{$X_{1}$} & \multirow[t]{2}{*}{$x_{2}$} & \multirow[t]{2}{*}{$x_{3}$} & \multirow{2}{*}{$\begin{array}{l}\text { Biodiesel } \\
\text { yield } \\
\%(v / v)\end{array}$} & \multicolumn{2}{|c|}{ Predicted } & \multicolumn{2}{|c|}{ Residual } \\
\hline & & & & & MRS & $\overline{\text { ANN }}$ & MRS & ANN \\
\hline 1 & 1 & 0 & 1 & 56.00 & 56.25 & 55.93 & -0.25 & 0.07 \\
\hline 2 & 1 & -1 & 0 & 60.00 & 59.88 & 60.63 & 0.13 & 0.63 \\
\hline 3 & 0 & 1 & -1 & 86.00 & 86.13 & 86.19 & -0.12 & 0.19 \\
\hline 4 & -1 & 1 & 0 & 78.00 & 78.13 & 78.02 & -0.12 & 0.02 \\
\hline 5 & 0 & 0 & 0 & 58.00 & 58.00 & 58.02 & 0.00 & 0.02 \\
\hline 6 & 0 & 1 & 1 & 76.00 & 75.88 & 75.98 & 0.13 & 0.02 \\
\hline 7 & -1 & -1 & 0 & 77.00 & 77.13 & 76.99 & -0.12 & 0.02 \\
\hline 8 & 0 & 0 & 0 & 58.00 & 58.00 & 58.02 & 0.00 & 0.02 \\
\hline 9 & 1 & 0 & -1 & 66.00 & 66.00 & 66.08 & 0.00 & 0.08 \\
\hline 10 & 0 & 0 & 0 & 58.00 & 58.00 & 58.02 & 0.00 & 0.02 \\
\hline 11 & -1 & 0 & -1 & 83.00 & 82.75 & 82.99 & 0.25 & 0.01 \\
\hline 12 & 0 & -1 & 1 & 75.00 & 74.88 & 75.02 & 0.13 & 0.02 \\
\hline 13 & 1 & 1 & 0 & 62.00 & 61.88 & 61.34 & 0.13 & 0.66 \\
\hline 14 & -1 & 0 & 1 & 73.00 & 73.00 & 73.00 & 0.00 & 0.00 \\
\hline 15 & 0 & -1 & -1 & 84.00 & 84.13 & 83.81 & -0.12 & 0.19 \\
\hline
\end{tabular}


Table 12 Test of significance for every regression coefficient

\begin{tabular}{llllllll}
\hline Source & DF & Seq. SS & Contribution (\%) & Adj. SS & Adj. MS & F-Value & P-Value \\
\hline$X_{1}$ & 1 & 561.13 & 34.81 & 561.13 & 561.13 & 13467.00 & 0.00 \\
$X_{2}$ & 1 & 4.50 & 0.28 & 4.50 & 4.50 & 108.00 & 0.00 \\
$X_{3}$ & 1 & 190.13 & 11.79 & 0.42 & 190.13 & 190.13 & 4563.00 \\
$X_{1}^{2}$ & 1 & 6.70 & 23.67 & 0.23 & 0.23 & 5.54 & 0.00 \\
$X_{2}^{2}$ & 1 & 381.50 & 28.99 & 446.77 & 446.77 & 10722.46 & 0.06 \\
$X_{3}^{2}$ & 1 & 467.31 & 0.02 & 467.31 & 467.31 & 11215.38 & 0.00 \\
$X_{1} X_{2}$ & 1 & 0.25 & 0.02 & 0.25 & 0.25 & 6.00 & 0.05 \\
$X_{2} X_{3}$ & 1 & 0.25 & 0.25 & 0.25 & 6.00 & 0.05 \\
\hline
\end{tabular}

Where: DF Degree of Freedom, Seq. SS Sequential Sum of Square, Adj. SS Adjusted Sum of Square, Adj. MS Adjusted Mean Square, F Fischer, P Probability

all the samples, while titanium $(\mathrm{T})$, vanadium $(\mathrm{V})$, chromium $(\mathrm{Cr})$, manganese $(\mathrm{Mn})$, arsenic $(\mathrm{As})$, gold $(\mathrm{Au})$, and tin $(\mathrm{Sn})$ showed the lowest relative abundance among others. The observation from this study, which implies that $\mathrm{K}$ is the major active component responsible for the activity of the catalyst in BPSM synthesis can be supported by the findings reported by Betiku et al. [35], where $\mathrm{K}$ with $59.3 \%$ has the highest concentration among other elements such as calcium, magnesium, phosphorous, and others present in calcinated cocoa pod husk used in biodiesel production from Azadirachta indica seed oil. In this study, BPSM reached the highest concentration of $58.48 \%$ at a calcination time of $5 \mathrm{~h}$ for the peak value. This observation could not only be caused by its macro mineral nature and maintenance of osmotic pressure, but also by its cell size in the plant, which influenced the photosynthesis and energy production found in potassium. The calcination also resulted in the sintering of small mineral aggregates and agglomerated particles, which explained the spongy nature. It had been reported that calcination always prevented leaching of potassium and may increase the reusability of catalyst during biodiesel production [35]. These effects were associated with higher heating values and cetane numbers of biodiesel.

\section{Quality characterization of $T$. peruviana biodiesel compared to other studies using the ASTM D6751 and EN 14214 standards, for example}

The quality of biodiesel obtained after the transesterification process was evaluated by subjecting the content and compositions of T. peruviana biodiesel to physicochemical analysis. The results obtained were compared with other published articles and also with ASTM D6751 and EN 14214 standards (Table 15). At room temperature, the $T$. peruviana biodiesel produced was liquid, brownish in color with a moisture content of 0.004. Observation from other researchers published showed no value, but the ASTM D6751 allowed to achieve a value $<0.03$ and EN 14214 of 0.02 . The density of $0.816 \mathrm{~g} / \mathrm{cm}^{3}$ was in reasonable agreement with other works and within the range specified by ASTM D6751 and EN 14214. The biodiesel acid value achieved was $0.508 \mathrm{mg}$ of $\mathrm{KOH} / \mathrm{g}$, which was higher than in other published work but within the prescribed ASTM D6751 (<0.8) and EN 14214 (0.5 max). The iodine value of $T$. peruviana biodiesel of $73.20 \mathrm{gI}_{2} /$ $100 \mathrm{~g}$ oil obtained was above the value recorded in [43] but lower than the result published in [35], and below the maximum limit of 120, prescribed by EN 14214. The saponification value, which is the number of milligrams of $\mathrm{KOH}$ required to neutralize the fatty acids resulting from the complete hydrolysis of $1 \mathrm{~g}$ of fat or oil, gives an indication of the nature of the fatty acids of oil and thus dependent on the average molecular weight of the fatty acids constituent of the oil. The value obtained was $126.648 \mathrm{mg} \mathrm{KOH} / \mathrm{g}$ oil, but no value was recorded by other researchers in the previously published works. The higher heating value (HHV) determined for the biodiesel in this study was $45.335 \mathrm{MJ} / \mathrm{kg}$, which takes into account the latent heat of vaporization of water in the combustion products. The cetane number, which is a measure of the fuel's ignition delay and combustion quality of the oil/fuel;

Table 13 Analysis of Variance (ANOVA) of regression equation

\begin{tabular}{llllllll}
\hline Source & DF & Seq.SS & Contribution (\%) & Adj. SS & Adj. MS & F-Value & P-Value \\
\hline Model & 8 & 1611.75 & 99.98 & 1611.75 & 201.47 & 4835.25 & 0.00 \\
Lack-of-Fit & 4 & 0.25 & 0.02 & 0.25 & 0.06 & 0.00 & $*$ \\
Pure Error & 2 & 0.00 & 0.00 & 0.00 & & \\
Total & 14 & 1612.00 & 100.00 & & \\
& & & $R^{2}=99.98 \%, \quad R^{2}$ (adj.) $=99.96 \%$, & $R^{2}$ (pred.) $=99.84 \%$ \\
\hline
\end{tabular}


Table 14 ANOVA for response surface quadratic model for intercept

\begin{tabular}{|c|c|c|c|c|c|c|c|}
\hline Term & Coefficient & Standard Error Coefficient & 95\% Cl Low & 95\% Cl High & T- Value & P-Value & VIF \\
\hline Constant & 58.00 & 0.1180 & 57.712 & 58.288 & 492.15 & 0.000 & - \\
\hline$x_{1}$ & -8.375 & 0.0722 & -8.5516 & -8.1984 & -116.05 & 0.000 & 1.00 \\
\hline$x_{2}$ & 0.75 & 0.0722 & 0.5734 & 0.9266 & 10.39 & 0.000 & 1.00 \\
\hline$x_{3}$ & -4.875 & 0.0722 & -5.0516 & -4.6984 & -67.55 & 0.000 & 1.00 \\
\hline$x_{1}^{2}$ & 0.25 & 0.1060 & -0.01 & 0.51 & 2.35 & 0.057 & 1.01 \\
\hline$x_{2}^{2}$ & 11.00 & 0.1060 & 10.74 & 11.26 & 103.55 & 0.000 & 1.01 \\
\hline$x_{3}^{2}$ & 11.25 & 0.1060 & 10.99 & 11.51 & 105.9 & 0.000 & 1.01 \\
\hline$x_{1} x_{2}$ & 0.25 & 0.1020 & 0.00 & 0.50 & 2.45 & 0.050 & 1.00 \\
\hline$x_{2} x_{3}$ & -0.25 & 0.1020 & -0.50 & 0.00 & -2.45 & 0.050 & 1.00 \\
\hline
\end{tabular}

as the higher the cetane number and the shorter the delay interval is, the greater the combustibility will be. Fuels with a low cetane number are difficult to start, hence producing smoke. The standard minimum specification value of the cetane number for biodiesel is within the range of 47-51 (ASTM D6751 and EN 14214). The value obtained by Betiku [35] was high (123.251), but the value obtained in this study reached only 72.926 . This may be attributed to the nature of the catalyst used during the transesterification process. Other properties, such as aniline point, diesel index, and API of the T. peruviana biodiesel were also evaluated and recorded. The $T$. peruviana diesel index (87.397) and aniline point (372.155) obtained were higher than that of neat diesel; the API (23.484) was lower a

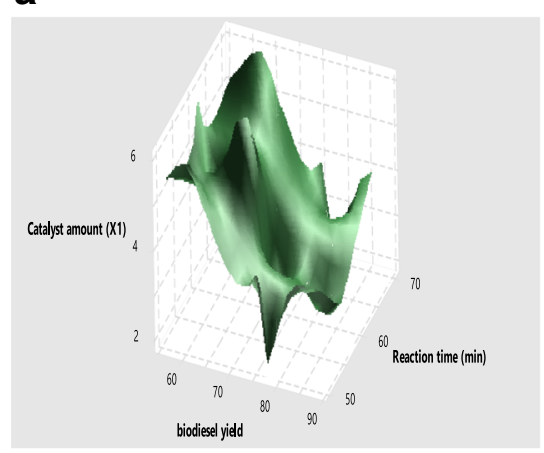

b

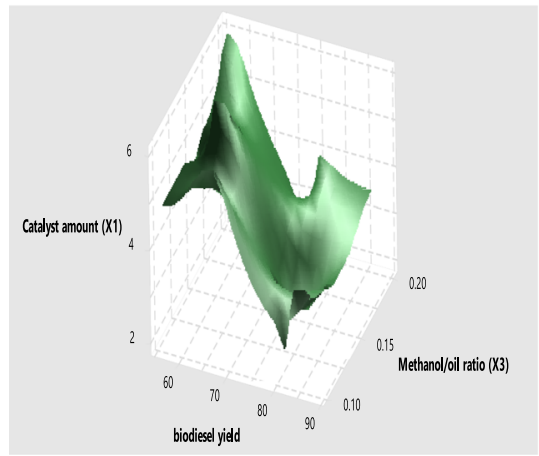

C

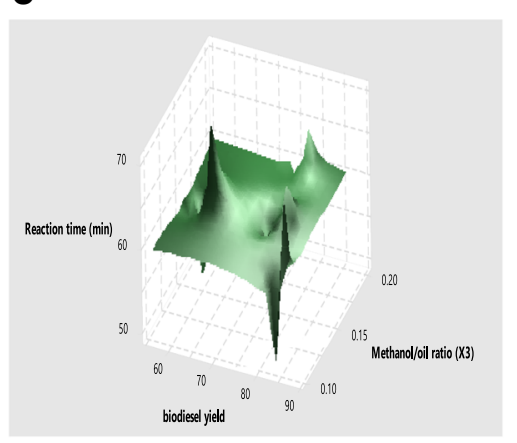

d

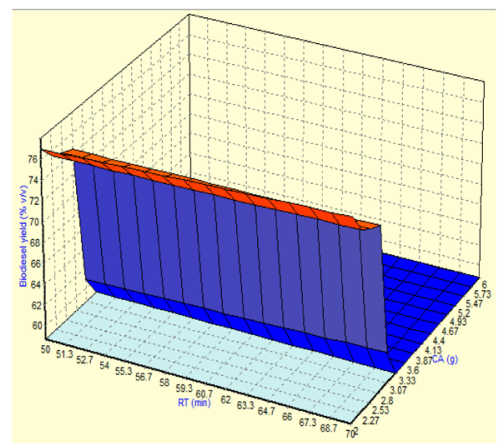

e

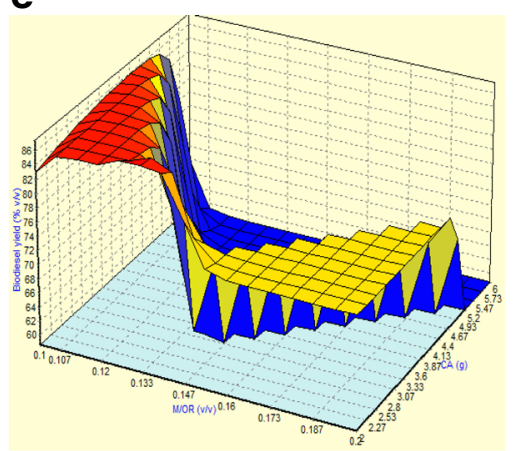

f

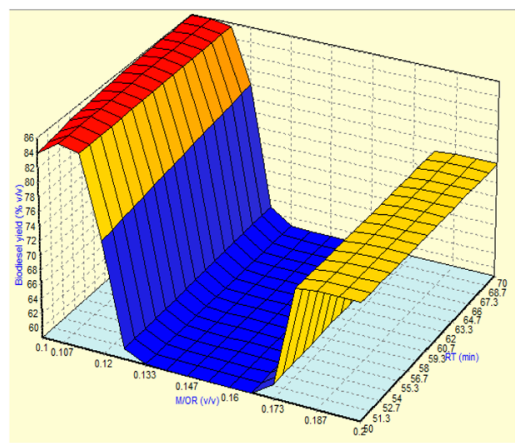

Fig. 4 a 3D surface plot of MRS showing interactive effect of catalyst amount and reaction time on biodiesel yield \% ( $/ / \mathrm{v})$; b catalyst amount and methanol/oil ratio on biodiesel yield $\%(\mathrm{v} / \mathrm{v})$; c reaction time and methanol/oil ratio on biodiesel yield \% $(\mathrm{v} / \mathrm{v})$. d 3D surface plot of ANN showing interactive effect of catalyst amount and reaction time on biodiesel yield \% ( $/ / \mathrm{v})$; e catalyst amount and methanol/oil ratio on biodiesel yield \%

$(\mathrm{v} / \mathrm{v})$; $\mathbf{f}$ reaction time and methanol/oil ratio on biodiesel yield \% $(\mathrm{v} / \mathrm{v})$ 


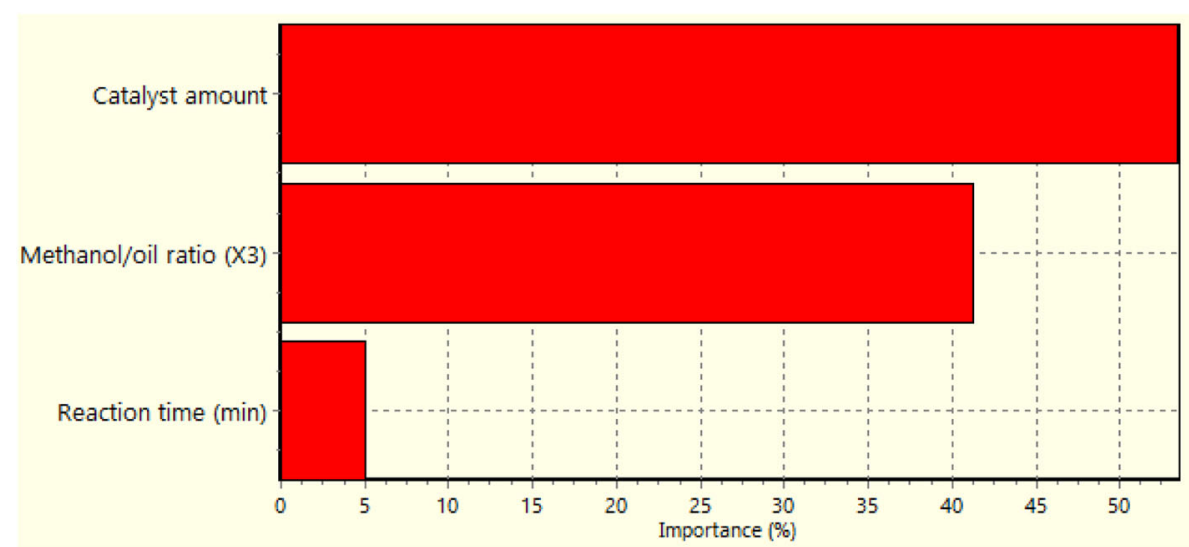

Fig. 5 Importance of selected variables considered on the percentage biodiesel production

compared to that of neat diesel, but was comparable to that which was obtained by other researchers using different seed oil biodiesel [70, 71].

\section{Comparing the fuel properties of $T$. peruviana oil with biodiesel}

The suitability of the T. peruviana biodiesel in I.C. engines was proved by the evaluation of the fuel properties. The results obtained are displayed in Table 16. It was observed from the parent oil (T. peruviana seed oil) to the biodiesel that the moisture content was reduced by $66.4 \%$, which showed very low moisture content of the biodiesel which was required in order to prevent or eliminate an engine knockout effect. The specific gravity increased by $1.6 \%$, which pointed to a significant increase in heat of vaporization and accelerated ignition when combustion occurred. The iodine value was reduced by $24.69 \%$, which implies that the biodiesel produced has a certain level of unsaturation [77, 78], whereas the acid value was reduced by $71.8 \%$, indicating that the biodiesel has a long shelf life [79, 80-83]. The saponification value was reduced by $30.86 \%$, suggesting a low concentration of triglycerides in biodiesel, while the density increased by $5.15 \%$. However, the high heating value further increased by $0.54 \%$, when converted to biodiesel, and the cetane number also increased by $19.11 \%$, which accounts for its greater combustion process ability, as a fuel with low a cetane number produces smoke, when used in an engine [80]. Other additional fuel properties, such as the aniline point increased by $29.68 \%$, and the diesel index increased by $22.15 \%$. The API decreased by $10.71 \%$ from oil to biodiesel. These results confirmed

Table 15: Qualities of T. peruviana biodiesel as compared with other researched work

\begin{tabular}{|c|c|c|c|c|c|c|c|c|c|}
\hline Properties & [81] & [44] & [31] & {$[82]$} & {$[83]$} & [35] & ASTM D6751 & EN 14214 & This study \\
\hline Density $\left(15^{\circ} \mathrm{C}, \mathrm{g} / \mathrm{cm}^{3}\right)$ & 0.839 & 0.875 & 0.86 & 0.87 & 0.866 & 0.887 & 0.84 & $0.86-0.90$ & 0.816 \\
\hline Acid value (mg KOH/g) & - & 0.057 & 0.3 & 0.2 & - & 0.46 & $<0.80$ & $0.5 \max$ & 0.508 \\
\hline Free fatty acid (mg KOH/g) & - & - & - & - & - & - & $<0.40$ & 0.25 max. & 0.254 \\
\hline lodine value $\left(\mathrm{g} \mathrm{I}_{2} / 100 \mathrm{~g}\right)$ & - & 69.9 & - & - & - & - & - & 120 max. & 73.20 \\
\hline Saponification value $(\mathrm{mg} \mathrm{KOH/g})$ & - & - & - & - & - & - & - & - & 26.648 \\
\hline Kinematic viscosity $\left(40{ }^{\circ} \mathrm{C}, \mathrm{mm}^{2} / \mathrm{s}\right)$ & 4.2 & 4.33 & 5.17 & 4.5 & 5.1 & 6 & - & - & 3.92 \\
\hline Cetane number & 47 & 61.5 & - & 54.2 & - & 123.25 & $47 \mathrm{~min}$ & $51 \mathrm{~min}$. & 234.58 \\
\hline Moisture content (wt. \%) & - & - & - & - & - & - & $<0.03$ & 0.02 & 0.0044 \\
\hline Specific gravity & - & - & - & - & - & - & $0.86-0.90$ & 0.85 & 0.913 \\
\hline Centane index & - & 62.9 & - & - & 58.97 & - & - & - & - \\
\hline Mean Molecular Mass & - & - & - & - & - & - & - & - & 2101 \\
\hline Higher Heating Value (MJ/kg) & - & - & - & - & - & - & - & - & 47.312 \\
\hline API & - & - & - & - & - & - & 36.95 & - & 23.484 \\
\hline Diesel index & - & - & - & - & - & - & 50.4 & - & 311.918 \\
\hline Aniline point $\left({ }^{\circ} \mathrm{F}\right)$ & - & - & - & - & - & - & 331 & - & 1328.24 \\
\hline
\end{tabular}


Table 16: Comparing the fuel properties of T. peruviana oil and biodiesel

\begin{tabular}{|c|c|c|}
\hline Parameters & $\begin{array}{l}\text { T. peruviana } \\
\text { oil }\end{array}$ & $\begin{array}{l}\text { T. peruviana } \\
\text { biodiesel }\end{array}$ \\
\hline Density $\left(\mathrm{g} / \mathrm{cm}^{3}\right)$ & 0.774 & 0.816 \\
\hline Moisture content (\%) & 0.0131 & 0.0044 \\
\hline Specific gravity & 0.8984 & 0.913 \\
\hline Mean Molecular mass & 973.87 & 2101 \\
\hline Acid value (mg KOH/g oil) & 3.8048 & 0.508 \\
\hline Saponification value (mg KOH/g oil) & 57.5025 & 26.648 \\
\hline lodine value ( $\mathrm{g} \mathrm{I}_{2} / 100 \mathrm{~g}$ oil) & 97.6 & 73.2 \\
\hline Peroxide value (meq. $\mathrm{O}_{2} / \mathrm{kg}$ oil) & 23.8 & - \\
\hline Higher heating value (MJ/kg) & 47.056 & 47.312 \\
\hline Cetane number & 140.998 & 234.58 \\
\hline API & 26 & 23.484 \\
\hline Diesel index & 181.94 & 311.918 \\
\hline Aniline point $\left({ }^{\circ} \mathrm{F}\right)$ & 699.77 & 1328.239 \\
\hline
\end{tabular}

that the produced $T$. peruviana biodiesel could serve as an alternative to the conventional diesel and its blends could improve fuel properties.

\section{Conclusions}

In conclusion, in this study, the pre-soaked calcinated BPSM was proved to serve as an alternative catalyst for biodiesel production from $T$. peruviana oil. $T$. peruviana seed was found to be rich in oil with an average yield of $44.00 \%(v / v)$, and the oil was highly unsaturated with a high FFA. The maximum experimental biodiesel yield obtained was $86.00 \%$ at a catalyst amount of $4 \mathrm{~g}$, a reaction time of $70 \mathrm{~min}$, and a methanol/oil ratio of $0.1(v / v)$. The properties of the T. peruviana biodiesel, as described in other earlier reports using the same feedstock with different catalysts as well as compared with ASTM D6751 and EN 14214, indicated that the produced biodiesel had properties which agreed to those reported in the literature. Hence, it can be concluded that $T$. peruviana biodiesel produced in the case where a blend could serve as an alternative to conventional diesel is environmentally friendly.

\section{Abbreviations}

AEOE: Aqueous enzymatic oil extraction; ANN: Artificial neural network; ANOVA: Analysis of variance; ASTM: American Society of Testing and Material; BPSM: Brette Pearl Spar Mable; CN: Cetane number; EDXRF: Electron diffractometer X-ray fluorescence; FAME: Fatty acid methyl ester; FFA: Free fatty acid; GC-MS: Gas chromatographic mass spectrometer; GR\&R: Gage repeatability and productivity; HHV: Higher heating value; I.C engine: Internal combustion engine; IV: lodine value; MRS: Minitab response surface; PV: Peroxide value; RSM: Response surface methodology; SV: Saponification value; VIF: Variance inflation factor

\section{Acknowledgements}

The authors would like to acknowledge the efforts of the Laboratory Technologists of the NASENIC Research Centre, Akure, Nigeria and the Laboratory Technologists of Chemistry Department of the University of Ilorin, Kwara State, Nigeria in carrying out the gas chromatographic analysis and the EDXRF spectrophotometer analysis during this research work. The authors are grateful to Dr. Ogunjimi O. A. for his interesting contributions during the research work.

\section{Funding}

This research work receive no fund from any institution or any government organization.

Availability of data and materials

All data are included in the article.

Raw data are not applicable.

\section{Declarations}

That the article is original, has not already been published in a journal, and is not currently under consideration by another journal.

\section{Authors' contributions}

TFA was involved in the research work and prepared the manuscript. BEO designed the experiment, supervised the work, and also carried out the extraction part of the work, while OMO performed the elemental calcination part of the work. Finally, MAI carried out the biodiesel production part and the analysis of biodiesel. All authors worked together to achieve the optimum outcome of this research work. All authors read and approved the final manuscript.

\section{Authors' information}

Dr. Adepoju T. F. is a B. Tech. graduate of Chemical Engineering from Ladoke Akintola University of Technology; he had his Master of Science and Doctor of Philosophy in Chemical Engineering from Obafemi Awolowo University, Nigeria. He is presently a lecturer and the Head of the Department, Chemical and Petrochemical Engineering Department, Akwa Ibom State University, Nigeria. His research interests focused on renewable and sustainable energy. Engr. Olatunbosun B. E. is a Master degree holder in Agricultural Engineering and a lecturer in Agricultural Engineering Department Akwa Ibom State University, Nigeria. His research areas focus on environmental engineering, process engineering, and renewable energy.

Dr. Olatunji O. M. is a PhD holder in Agricultural Engineering and a lecturer in Agricultural Engineering Department Akwa Ibom State University, Nigeria. His research area focuses on processing and renewable energy. Ibeh, M. A. is a master degree holder in Petroleum Engineering. She is presently a lecturer in the Department of Chemical and Petrochemical Engineering, Akwa Ibom State University, Nigeria. Her research interest focuses on renewable and sustainable energy, green chemistry, reservoir engineering, and biochemical engineering.

Ethics approval and consent to participate Not applicable. 


\section{Consent for publication}

Not applicable.

\section{Competing interests}

The research article is an original work of authors and was truly carried out by authors. The authors declare that they have no competing interests.

\section{Publisher's Note}

Springer Nature remains neutral with regard to jurisdictional claims in published maps and institutional affiliations.

\section{Received: 28 December 2017 Accepted: 15 June 2018}

\section{Published online: 23 July 2018}

\section{References}

1. Graboski MS, McCormick RL (1998) Combustion of fat and vegetable oil derived fuels in diesel engines. Progress in Energy Combustion Science 24:125-164

2. Ma F, Hanna MA (1999) Biodiesel production: a review. Bioresources Technology 70:1-15

3. Martins MI, Pires RF, Alves MJ, Hori CE, Reis MHM, Cardoso VL (2013) Transesterification of soybean oil for biodiesel production using hydrotalcite as basic catalyst. Chem Eng Trans 32:817-822

4. Lotero E, Liu Y, Lopez DE, Suwannakarn K, Bruce DA, Godwin JG (2005) Synthesis of biodiesel via acid catalysis. Industrial Engineering Chemical Resouces 44:5353-5363

5. Zhang Y, Dube MA, McLean DD, Kates M (2003) Biodiesel production from waste cooking oil: process design and technological assessment. Bioresour Technol 89:1-16

6. Abu-Arabi MK, Allawzi MA, Al-Zoubi HS, Tamimi A (2006) Extraction of jojoba oil by pressing and leaching. Chem Eng J 76:61-65. https://doi.org/ 10.1016/S1385-8947(99)00119-9

7. Herak D, Kabutey A, Divisova M, Svatonava T (2012) Comparison of the mechanical behaviour of selected oilseeds under compression loading. Not Bot Horti Agrobo 40(2):227-232

8. Kartika IA, Pontalier PY, Rigal L (2006) Extraction of sunflower by twin screw extruder: screw configuration and operating condition effects. Bioresour Technol 97:2302-2310

9. Suchan P, Pulkrabova J, Hajslova J, Vladimir K (2004) Pressurized liquid extraction in determination of polychlorinated biphenyls and organochlorine pesticides in fish samples. Anal Chim Acta 520:193-200. https://doi.org/10.1016/j.aca.2004.02.061

10. Betiku E, Adepoju TF, Omole AK, Aluko SE (2012) Statistical approach to the optimization of oil from beniseed (sesamium indicum) oilseeds. J Food Sci Eng 2(2):351-357

11. Li H, Pordesimo L, Weisis J (2004) High intensity ultrasound-assisted extraction of oil from soybeans. Food Res Int 37:731-738

12. Ibiari NN, Abo El-Enin SA, Attia NK, El-Diwani G (2010) Ultrasonic comparative assessment for biodiesel production from rapeseed. Journal of American Science 6(12):937-943

13. Rosenthal A, Pyle DL, Niranjan K (1996) Aqueous and enzymatic processes for edible oil extraction. Enyme Chimica Slovenica 19:402-420

14. Jiang L, Hua D, Wang Z (2010) Aqueous enzymatic extraction of peanut oil and protein hydrolysates. Food Bioprod Process 88(23):233-238. https://doi.org/10.1016/jfld.2009.08.002

15. Hoogerstraete VT, Onghena B, Binnemans K (2013) Homogeneous Liquid-Liquid Extraction of Rare Earths with the Betaine-Betainium Bis (trifluoromethylsulfonyl) imide lonic Liquid System. 14:21353-21377. https://doi.org/10.3390/ijms 141121353

16. Terigar BG, Balasubramanian S, Boldor D, Xu Z, Lima M, Sabliov CM (2001) Continuous microwave-assisted isoflavone extraction system: design and performance evaluation. Bioresour Technol 101(7):2466-2471

17. Rodríguez MJR, Navarrete A, Rivero JCS, Escoffie PA, Uribe JAR, (2012) Extraction and Characterization of Oil from Thevetia peruviana Using Supercritical $\mathrm{CO}_{2}$, Universidad Autónoma de Yucatán, Periférico Nte. Km 33. 5, Col Chuburna Hidalgo Inn, Mérida, Yucatán; C. P. 97203, Mexico

18. Pan X, Niu G, Liu H (2002) Comparison of microwave-assisted extraction and conventional extraction techniques for the extraction of tanshinones from Salvia miltiorrhiza bunge. Biochem Eng J 12:71-77

19. Perez-Serradilla JA, Japon-Lujon R, Luque deCastro MD (2000) Simultaneous microwave-assisted solid-liquid extraction of polar and non-polar compounds from alperujo. Anal Chim Acta 602:82-88
20. Kim HJ, Kang BS, Kim MJ, Park YM, Kim DK, Lee JS, Lee KY (2004) Transesterification of vegetable oil to biodiesel using heterogeneous base catalyst. Catalyst Today 93:315-320

21. Umer R, Anwer F, Asharf M, Yusup S (2011) Application of response surface methodology for the optimizing transesterification of Moringa olifera oil. Energy Convers Manag 52:3034-3042

22. Betiku E, Adepoju TF (2013) Sorrel (Hibiscus sabdariffa) seed oil extraction optimization and quality characterization. American Chemical Science Journal 3(4):449-458

23. Adepoju TF, Okunola AA, Olamide O (2013) Optimization, kinetic degradation and quality characterization of oil extracted from Nigeria Hibiscus sabdariffa oilseeds. International Journal of Engineering Research and Technology 2(11):3856-3875

24. Betiku E, Adepoju TF, Akinbiyi KO, Seyi EA (2012) Statistical approach to the optimization of oil from Beniseed (Sesamum indicum) oilseeds. J Food Sci Eng 2(2):351-357 https://www.academia.edu/23782490

25. Nehdi I, Omri S, Khalil Ml, Al-Resayes SI (2010) Characteristics and chemical composition of date palm (Phoenix canariensis) seeds and seed oil. Journal of Industrial Crops and Products 32:360-365

26. Pramanik K (2003) Properties and use of Jatropha curcas oil and diesel fuel blends in compression ignition engine. Renew Energy 28:239-248

27. Srivastava A, Prasad R (2000) Triglycerides-based diesel fuels. Renew Sust Energ Rev 4:111-133

28. Junaid A, Yusuf S, Bokhari A, Kamil RN (2014) Study of fuel properties of rubber seed oil based biodiesel. Energy Convers Manag 78:266-275

29. Knothe G, Steidley KR (2005) Kinematic viscosity of biodiesel fuel components and related compounds. Influence of compound structure and comparison to Petrodiesel fuel components. Fuel 81:1059-1065

30. Liu GC, Wang XL (2007) Optimization of critical medium components using response surface methodology for biomass and extracellular polysaccharide production by Agaricus blazei. Applied Microbiology Biotechnology 74:78-83

31. Dhoot SB, Jaju DR, Deshmukh SA, Panchal BM, Sharma MR (2011) Extraction of Thevetia peruviana Seed Oil and Optimization of Biodiesel Production Using Alkali-catalyzed Methanolysis. Journal of Alternate Energy Sources and Technologies 2(2):8-16

32. Kian FY, Teong Lee K, Ceccato R, Abdullah AZ (2011) Production of biodiesel from Jatropha curcas $\mathrm{L}$. oil catalyzed by $\mathrm{SO}_{4}{ }^{2-} / \mathrm{ZrO}_{2}$ Catalyst: Effect of interaction between process variables. Biosources Technology 102:4285-4289

33. Okolie PN, Uaboi-Egbenni PO, Ajekwene AE (2012) Extraction and quality evaluation of sandbox tree seed (Hura crepitan) oil. World Journal of Agricultural Sciences 8(4):359-365

34. Adepoju TF (2014) Response surface methodology (RSM) a good optimizer for transesterification reaction of Chrysophyllum albidium seed oil to Chrysophyllum albidium oil biodiesel. International Journal of Chemical and Process Engineering Research 1(4):32-42

35. Betiku E, Ajala SO (2014) Modeling and optimization of Thevetia peruviana (yellow oleander) oil biodiesel synthesis via Musa paradisiacal (plantain) peels as heterogeneous catalyst: a case of artificial neural network vs. response surface methodology. Ind Crop Prod 53:314-322

36. Ana GR, Udofia BG (2015) Characterization of oil and biodiesel produced from Thevetia peruviana (yellow oleander) seeds. International Journal of Sustainable and Green Energy 4(4):150-158

37. Betiku E, Adepoju TF (2012) Methanolysis optimization of sesame (Sesamum indicum) oil to biodiesel and fuel quality characterization. International Journal of Energy and Environmental Engineering 4(9):ISSN 2251-6832

38. Zhang XW, Huang W (2011) Optimization of the transesterification reaction from cottonseed oil using a statistical approach. 33:12 Energy Sources, Part A: Recovery, Utilization, and Environmental Effects https://doi.org/10.1080/ 15567031003627971

39. Ferdous KM, Uddin MR, Khan RM, Islam MA (2013) Preparation of biodiesel from soybean oil by using heterogeneous catalyst. International Journal of Energy and Environment 4(2):243-252

40. Choi WY, Kim GV, Lee SY, Leec HY (2014) Biodiesel production from Scenedesmus sp. through optimized in situ acidic transesterification process Chem. Biochemical Engineering Quality 28(3):367-374

41. Xie W, Peng $H_{\text {, Chen } L}$ (2006) Transesterification of soybean oil catalyzed by potassium loaded on alumina as a solid-base catalyst. Appl Catal 300:67-74

42. Shibasaki-Kitagawa N, Honda H, Kuribayashi H, Toda T, Fukumura T, Yonemoto T (2007) Biodiesel production using anionic ion-exchange resin as heterogeneous catalyst. Bioresour Technol 98:416-421 
43. Deka DC, Basumatary S (2011) High quality biodiesel from yellow oleander (Thevetia peruviana) seed oil. Biomass Bioenergy 35:1797-1803

44. KoohiKamali S, Tan CP, Ling TC (2012) Optimization of sunflower oil transesterification process using sodium methoxide. The Scientific World Journal 2012:Article ID 475027. https://doi.org/10.1100/2012/475027

45. Kakati DK, Boraa MM, Gogoib P, Dekaa DC (2014) Synthesis and characterization of yellow oleander (Thevetia peruviana) seed oil-based alkyd resin. Ind Crop Prod 52:721-728

46. Jahirul MI, Koh W, Brown RJ, Senadeera W, O'Hara I, Moghaddam L (2014) Biodiesel production from non-edible beauty leaf (Calophyllum inophyllum) oil: process optimization using response surface methodology (RSM). Energies 7:5317-5331

47. Yan S (2010) Review of two statistical software packages-Minitab and SPSS. STAT582 HW

48. Bourquin J, Schmidli H, Hoogevest P, Leuenberger H (1998a) Advantages of artificial neural networks (ANNs) as alternative modeling technique for data sets showing non-linear relationships using data from a galenical study on a solid dosage form. European Journal Pharmaceutical Sciences 7:5-16

49. Bourquin J, Schmidli H, Hoogevest P, Leuenberger H (1998b) Pitfalls of artificial neural networks (ANNs) modeling technique for data sets containing outlier measurements using a study on mixture properties of a direct compressed dosage form. European Journal Pharmaceutical Sciences 7:17-28

50. Sulaiman A, Nikbakht AM, Khatamifar M, Tabatabaei M, Ali Hassan M (2010) Modeling anaerobic process for waste treatment: new trends and methodologies. In: Dan Y (ed) Biology, environment and chemistry, in selected, peer reviewed papers from the 2010 International Conference on Biology, Environment and chemistry (ICBEC 2010), in Hong Kong. International proceedings of chemical, biological and Environmental Engineering, pp 32-36

51. Ghobadiana H, Rahimia AM, Nikbakhta G, Najafia TF, Yusaf (2008) Diesel engine performance and exhaust emission analysis using waste cooking biodiesel fuel with an artificial neural network. Renew Energy 34(4):976-982

52. Ramadhas AS, Jayaraja S, Muraleedharana C, Padmakumari K (2006) Artificial neural networks used for the prediction of the cetane number of biodiesel. Renew Energy 31(15):2524-2533

53. Shivakumara P, Srinivasa Paib BR, Raob S (2011) Artificial neural network based prediction of performance and emission characteristics of a variable compression ratio $\mathrm{Cl}$ engine using WCO as a biodiesel at different injection timings. Appl Energy 88(7):2344-2354

54. Canakci M, Erdil A, Arcaklioğlu E (2006) Applied energy performance and exhaust emissions of a biodiesel engine. Appl Energy 83(6):594-605

55. Najafi G, Ghobadian BF, Yusaf T, Rahimi H (2007) Combustion analysis of a $\mathrm{Cl}$ engine performance using waste cooking biodiesel fuel with an artificial neural network aid. Am J Appl Sci 4(10):756-764

56. Moradi GR, Dehghani S, Khosravian F, Arjmandzadeh A (2013) The optimized operational conditions for biodiesel production from soybean oil and application of artificial neural networks for estimation of the biodiesel yield. Renew Energy 50:915-920

57. Canakci M, Ozsezen AN, Arcaklioglu E, Erdil A (2009) Prediction of performance and exhaust emissions of a diesel engine fueled with biodiesel produced from waste frying palm oil. Expert Syst Appl 36(5):9268-9280

58. Çay Y, Çiçek A, Kara F, Sağiroğlu S (2012) Prediction of engine performance for an alternative fuel using artificial neural network. Appl Therm Eng 37:217-225

59. Yuste AJ, Dorado MP (2006) A neural network approach to simulate biodiesel production from waste olive oil. Energy Fuel 20(1):399-402

60. Schinas P, Karavalakis G, Davaris C, Anastopoulos G, Karonis D, Zannikos F (2009) (Cucurbita pepo L) pumpkin seed oil as an alternative feedstock for the production of biodiesel in Greece. Biomass Bioenergy 33:44-49

61. Panwal JH, Viruthagiri T, Baskar G (2011) Statistical modeling and optimization of enzymatic milk fat splitting by soybean lecithin using response surface methodology. International Journal of Nutrition and Metabolism 3:50-57

62. Datta D, Kumar S (2012) Modeling and optimisation of recovery process of glycolic acid using reactive extraction. International Journal of Chemical Engineering and Applications 3:141-146

63. Patel S, Kothari D, Goyal A (2011) Enhancement of dextransucrase activity of Pediococcus pentosaceus SPAm1 by response surface methodology. Indian Jour-nal of Biotechnology 10:346-351

64. Sudamalla P, Saravanan P, Matheswaran M (2012) Optimisation of operating parameters using response surface methodology for adsorption of crystal violet by activated carbon prepared from mango kernel. Sustainable Environment Research 22:1-7

65. Haider MA, Pakshirajan K (2007) Screening and optimization of media constituents for enhancing lipolytic activity by a soil microorganism using statistically designed experiments. Applied Biochemical and Biotechnology 141:377-390

66. Joglekar M, May AT (1987) Product excellence through design of experiments. Cereal Foods World 32:857-868

67. Mcginely L (1991) Analysis and quality control for processing and processed fats. In: Rossell JB, Pritchard JLR (eds) Analysis of oilseeds, fats, and fatty foods. Elsevier Applied Science, London, pp 460-470

68. Meher LC, Sagar DV, Naik SN (2006) Technical aspect of biodiesel production by transesterification - a review. Renewal and Sustainable Energy Reviews 10:248

69. Ramos LP, Domingo AK, Saad EB, Wilhelm HM (2008) Optimization of the ethanolysis of Raphanus sativus (L. Var.) crude oil applying the response surface methodology. Bioresour Technol 99:1837-1845

70. Rakopoulos CD, Antonopoulos KA, Hountalas DT, Giakoumis EG (2006) Comparative performance and emissions of a direct injection diesel engine using blends of diesel fuel with vegetable oils or biodiesels of various origins. Energy Conversion Management 47:3272-3287

71. Haldar SK, Ghosh BB, Nag A (2009) Utililization of unattended putranjiva roxburghii non-edible oil as fuel in diesel engine. Journal of Renewable Energy 34:343-347

72. Udayakumar R, Gopalakrishnan K (2014) GC-MS analysis of phytocompounds of leaf and stem of Marsilea quadrifolia (L.). International Journal of Biochemistry Research and Review 4(6):517-526

73. Tiwari AK, Kumar A, Raheman H (2007) Biodiesel production from Jatropha oil (Jatropha curcas) with high free fatty acids: an optimized process. Biomass Bioenergy 31:569-575

74. Yuan X, Liu J, Zeng G, Shi J, Tong J, Huang G (2008) Optimization of conversion of waste rapeseed oil with high FFA to biodiesel using response surface methodology. Renew Energy 33:1678-1684

75. Niladevi KN, Sukumaran RK, Jacob N, Anisha GS, Prema P (2009) Optimization of laccase production from a novel strain-Streptomyces psammoticus using response surface methodology. Microbiol Res 164:105-113

76. Baoxin Z, Xiangjing $W$, Wensheng $X$ (2011) Optimization of fermentation medium for enhanced production of milbemycin by a mutant of Streptomyces bingchenggensis BC-X-1 using response surface methodology African. J Biotechnol 10(37):7225-7235

77. Tomasevic AV, Marinkovic SS (2003) Methanolysis of used frying oils. Fuel Process Technology 81:1-6

78. Nakpong P, Wootthikanokkhan S (2010) Roselle (Hibiscus sabdariffa L.) oil as an alternative feedstock for biodiesel production in Thailand. Fuel 89:1806-1811

79. Mahmoud AA, Khaled A, Selim KA, Abdel-Baki, MR (2011) Physico-chemical and oxidative stability characteristics of roselle (Hibiscus sabdariffa L.) seed oil as by-product, www.fayoum.edu.eg/Agriculture/FoodSciences/pdf/ Drkhaled3.pdf

80. Adepoju TF (2012) Sorrel (Hisbiscus sabdariffa linn) seed oil extraction and biodiesel production using Response Surface methodology. Master's thesis OAU, lle-lfe

81. Balusamy T, Marappan R (2009) A comparative analysis on the performance and emission characteristics of thevetia peruviana seed oil (TPSO) with other non-edible oil in Cl engine. International Energy Journal 10:93-100

82. Adebowale KO, Adewuyi A, Ajulo KD (2012) Examination of fuel properties of the methyl esters of Thevetia peruviana seed oil. International Journal of Green Energy 9:297-307

83. Yarkasuwa Cl, Wilson D, Michael E (2013) Production of biodiesel from yellow oleander (Thevetia peruviana) oil and its biodegradability. JKCS 57: 377-381 